\title{
Simulating atmospheric composition over a South-East Asian tropical rainforest: performance of a chemistry box model
}

\author{
T. A. M. Pugh ${ }^{1}$, A. R. MacKenzie ${ }^{1}$, C. N. Hewitt ${ }^{1}$, B. Langford ${ }^{1}$, P. M. Edwards ${ }^{2}$, K. L. Furneaux ${ }^{2, \dagger}$, D. E. Heard ${ }^{2}$, \\ J. R. Hopkins ${ }^{3}$, C. E. Jones ${ }^{4}$, A. Karunaharan ${ }^{5}$, J. Lee $^{3}$, G. Mills ${ }^{6}$, P. Misztal ${ }^{7,8}$, S. Moller ${ }^{4}$, P. S. Monks ${ }^{5}$, and \\ L. K. Whalley ${ }^{2}$ \\ ${ }^{1}$ Lancaster Environment Centre, Lancaster University, Lancaster, UK \\ ${ }^{2}$ School of Chemistry, University of Leeds, Leeds, UK \\ ${ }^{3}$ National Centre for Atmospheric Science, University of York, York, UK \\ ${ }^{4}$ Department of Chemistry, University of York, York, UK \\ ${ }^{5}$ Department of Chemistry, University of Leicester, Leicester, UK \\ ${ }^{6}$ School of Environmental Sciences, University of East Anglia, UK \\ ${ }^{7}$ Centre for Ecology and Hydrology Edinburgh, U.K. \\ ${ }^{8}$ School of Chemistry, The University of Edinburgh, U.K. \\ ${ }^{\dagger}$ Sadly passed away on 28 July 2009
}

Received: 28 August 2009 - Published in Atmos. Chem. Phys. Discuss.: 16 September 2009

Revised: 11 December 2009 - Accepted: 4 January 2010 - Published: 14 January 2010

\begin{abstract}
Atmospheric composition and chemistry above tropical rainforests is currently not well established, particularly for south-east Asia. In order to examine our understanding of chemical processes in this region, the performance of a box model of atmospheric boundary layer chemistry is tested against measurements made at the top of the rainforest canopy near Danum Valley, Malaysian Borneo. Multivariate optimisation against ambient concentration measurements was used to estimate average canopy-scale emissions for isoprene, total monoterpenes and nitric oxide. The excellent agreement between estimated values and measured fluxes of isoprene and total monoterpenes provides confidence in the overall modelling strategy, and suggests that this method may be applied where measured fluxes are not available, assuming that the local chemistry and mixing are adequately understood. The largest contributors to the optimisation cost function at the point of best-fit are $\mathrm{OH}(29 \%)$, NO $(22 \%)$ and total peroxy radicals (27\%). Several factors affect the modelled VOC chemistry. In particular concentrations of methacrolein (MACR) and methyl-vinyl ketone (MVK) are substantially overestimated, and the hydroxyl radical $(\mathrm{OH})$
\end{abstract}

concentration is substantially underestimated; as has been seen before in tropical rainforest studies. It is shown that inclusion of dry deposition of MACR and MVK and wet deposition of species with high Henry's Law values substantially improves the fit of these oxidised species, whilst also substantially decreasing the $\mathrm{OH}$ sink. Increasing $\mathrm{OH}$ production arbitrarily, through a simple $\mathrm{OH}$ recycling mechanism, adversely affects the model fit for volatile organic compounds (VOCs). Given the constraints on isoprene flux provided by measurements, a substantial decrease in the rate of reaction of VOCs with $\mathrm{OH}$ is the only remaining option to explain the measurement/model discrepancy for $\mathrm{OH}$. A reduction in the isoprene+ $\mathrm{OH}$ rate constant of $50 \%$, in conjunction with increased deposition of intermediates and some modest $\mathrm{OH}$ recycling, is able to produce both isoprene and $\mathrm{OH}$ concentrations within error of those measured. Whilst we cannot rule out an important role for missing chemistry, particularly in areas of higher isoprene flux, this study demonstrates that the inadequacies apparent in box and global model studies of tropical VOC chemistry may be more strongly influenced by representation of detailed physical and micrometeorological effects than errors in the chemical scheme. 


\section{Introduction}

Global emissions of non-methane biogenic volatile organic compounds (BVOCs) are estimated to total $1150{\mathrm{Tg} \mathrm{C} \mathrm{yr}^{-1}}^{-1}$ (Guenther et al., 1995) and exceed those of their anthropogenic counterparts by a factor of 10 (WMO, 1995). Furthermore BVOCs typically have much shorter atmospheric lifetimes than anthropogenic VOCs and hence are believed to play a dominant role in the chemistry of the planetary boundary layer (PBL) and lower troposphere (Fuentes et al., 2000). A modelling study by Poisson et al. (2000) found that BVOCs could affect the composition of the entire troposphere due to the formation of longer-lived intermediates (e.g. CO), with strong increases in $\mathrm{O}_{3}$ and depletion in boundary layer $\mathrm{OH}$ concentrations being observed. Convection of $\mathrm{BVOC}$ oxidation products is a major source of $\mathrm{HO}_{\mathrm{x}}$ in the upper atmosphere (Poisson et al., 2000; Tan et al., 2001), whilst relatively long-lived oxides of nitrogen such as PAN can influence remote tropospheric $\mathrm{NO}_{\mathrm{x}}$, and hence ozone chemistry. Much work has been carried out on defining the reactions of these species (Jenkin et al., 2007; Saunders et al., 2003; Pinho et al., 2005), however, due to the number of compounds and complexity of the reaction schemes involved, their precise roles in controlling chemical budgets and processes in the atmosphere are poorly understood.

Over half the world's forests are found in the tropics, and, due to the prevailing high temperatures and solar fluxes, they are believed to account for almost half of all BVOC emissions to the atmosphere (Guenther et al., 1995). In recent years knowledge of tropical BVOC emissions and chemistry has been greatly increased by several measurement studies (e.g., Kuhn et al., 2004, 2007; Karl et al., 2007) and modelling studies (e.g., Lelieveld et al., 2008; Butler et al., 2008; Ganzeveld et al., 2008; Kubistin et al., 2008). In particular, flaws have been suggested in the current understanding of the reaction of isoprene and $\mathrm{OH}$ under low $\left[\mathrm{NO}_{\mathrm{x}}\right]$ conditions, resulting in questions about current understanding of global oxidant budgets.

Rapid land-use change makes it imperative to understand the chemistry of tropical forests, both for a holistic understanding of natural processes, and to predict the effect of such land-use changes on local/regional photochemistry and climate change. Therefore it is important to test current atmospheric chemistry models, currently optimised for the polluted mid-latitudes, in this relatively pristine environment. Reproducing measurements at box-model level is an important step towards generating accurate predictions from global and regional models.

This study tests the performance of the CiTTyCAT box model of atmospheric chemistry against measurements made at Bukit Atur, Sabah, Malaysian Borneo, as part of the Oxidant and particle photochemical processes above a SouthEast Asian tropical rain forest (OP3-Danum-08) field campaign (Hewitt et al., 2010). Forest in Borneo, including the Bukit Atur measurement site, is principally lowland ever- green broadleaf rainforest (Schmitt et al., 2008). Structurally and floristically, it is very different to the rainforest of Amazonia (Hewitt et al., 2010). Seasonal cycles are weak, with dry periods of greater than 1 month absent or rare, cf. to Amazonia or Equatorial Africa where most of the rainforest experiences a significant dry season (Walsh, 1996). The average peak daytime temperature of $27^{\circ} \mathrm{C}$ is less than observations in Amazonia of $28-32^{\circ} \mathrm{C}$ (Karl et al., 2007) and $>30^{\circ} \mathrm{C}$ (Kuhn et al., 2007). The analysis herein pays particular attention to the replication of the concentrations of BVOCs and their oxidants under the low $\mathrm{NO}_{\mathrm{x}}$ conditions observed. First, the measurement site (Sect. 2) and model parametrisation (Sect. 3) are outlined. Then the model is used to generate estimates of biogenic emissions from the site (Sect. 4) and the resultant model output is compared to observations and improvements suggested (Sect. 5). This is followed by an investigation of the relationship between isoprene and $\mathrm{OH}$ (Sect. 6).

\section{Measurement site description}

The OP3-Danum-08 field campaign was carried out in three phases: (i) ground-based measurements only, during April/May 2008 (OP3-1), (ii) a reduced set of flux and concentration measurements at a nearby oil palm estate during May/June (OP3-2), and (iii) both ground and aircraft measurements, during June/July 2008 (OP3-3). We focus here on measurements made during OP3-1. Groundbased measurements of atmospheric composition were primarily made at the Bukit Atur Global Atmospheric Watch (GAW) station $\left(4^{\circ} 58^{\prime} 59^{\prime \prime} \mathrm{N}, 117^{\circ} 50^{\prime} 39^{\prime \prime} \mathrm{E}\right)$ (Hewitt et al., 2010). These measurements included concentrations of NO, $\mathrm{NO}_{2}, \mathrm{NO}_{\mathrm{y}}, \mathrm{HONO}\left(\mathrm{OP} 3-3\right.$ only), $\mathrm{O}_{3}, \mathrm{OH}, \mathrm{HO}_{2}$ (OP33 only), $\mathrm{HO}_{2}+\mathrm{RO}_{2}, \mathrm{PAN}$, organic nitrates, isoprene, total and speciated monoterpenes and oxygenated organic compounds (formaldehyde and glyoxal). Fluxes of isoprene, total monoterpenes, $\mathrm{O}_{3}$, latent and sensible heat were also measured. Physical parameters measured included relative humidity, wind, mixing height and $\mathrm{J}\left(\mathrm{O}^{1} \mathrm{D}\right)$. A detailed description of the site and measurements is given in Hewitt et al. (2010).

The Bukit Atur (BA) GAW site is situated at an altitude of $437 \mathrm{~m}$ a.m.s.l., on a small hill approximately $260 \mathrm{~m}$ above the surrounding valley floor. The top of the hill features a small grassy clearing approximately $150 \mathrm{~m}$ by $50 \mathrm{~m}$ surrounded by secondary rainforest, rising to $\sim 10 \mathrm{~m}$ on three sides. The surrounding rainforest is either virgin or has not been logged since 1988 (Tangki and Chappell, 2008). A $100 \mathrm{~m}$ high steelframed measurement tower has been erected in the centre of the clearing as part of the World Meteorological Organisation Global Atmospheric Watch site that has been established at BA. The measurements used in this report were made at $\sim 5 \mathrm{~m}$ above ground level in this clearing, with the exception of PTR-MS measurements of BVOC concentrations 
and fluxes which were made at $75 \mathrm{~m}$, and PAN measurements which were made at $30 \mathrm{~m}$. References to measurement heights in this paper are always relative to the top of the hill.

It is possible that the 5-m measurements are effectively within the canopy. To ascertain whether this is indeed the case $\mathrm{NO}_{\mathrm{x}}$ measurements made at a nearby under-canopy site $\left(4^{\circ} 58^{\prime} 50^{\prime \prime} \mathrm{N}, 117^{\circ} 51^{\prime} 19^{\prime \prime} \mathrm{E}\right)$ are compared with those made in the boundary layer by an aircraft and those made at $5 \mathrm{~m}$ at BA. The in-canopy measurements $(8 \mathrm{~m}$ above soil surface) display significantly higher levels of NO (316 pptv as opposed to $37 \mathrm{pptv}$ in the median at midday). However the aircraft and 5-m measurements of $\mathrm{NO}$ and $\mathrm{NO}_{2}$ show good agreement (Hewitt et al., 2009), suggesting that the 5-m measurements may indeed be regarded as representative of the well-mixed boundary layer during daytime. Unlike $\mathrm{NO}_{\mathrm{x}}$, isoprene measurements during OP3-1 are on average 36\% lower at $75 \mathrm{~m}$ than at $5 \mathrm{~m}$, indicating that isoprene does show a gradient in the surface layer. This is because the ratio of emission rate to chemical loss rate is much greater for isoprene than for NO. No such gradient is discernible for monoterpenes which have a lower emission rate. Good agreement is seen for $75-\mathrm{m}$ and boundary layer aircraft measurements of isoprene Hewitt et al. (2009). Model calculations suggest that, at most, $\mathrm{OH}$ concentrations would increase by $30 \%$ between $5 \mathrm{~m}$ and $75 \mathrm{~m}$ as a result of the gradient. An increase of this magnitude is within the uncertainty of the measurements and, since it is an increase, would not adversely affect the analysis carried out in this study. As explained in Sect. 6, there is considerable uncertainty over whether isoprene is a significant net $\mathrm{OH}$ sink at all. 5-m and aircraft measurements of $\mathrm{OH}$ concentration show close agreement, supporting the assertation that for most species (i.e. those lacking strong surface emission) the 5-m measurement height on top of the hill is representative of, the daytime mixed layer. At nighttime, stratification within the clearing (Pugh et al., 2010) means that these measurements cannot be assumed to represent the nocturnal boundary layer. This paper concentrates on the daytime measurements, drawing only limited comparisons with measurements made during the night.

\section{Model description and parametrisation}

The CiTTyCAT atmospheric chemistry model (Wild et al., 1996; Evans et al., 2000; Emmerson et al., 2004; Donovan et al., 2005) was run in stationary-box mode at ground level over the Bukit Atur GAW site. Unless otherwise stated, all model species are allowed to evolve freely and are not constrained to observations. Hence, the model provides a bridge between 0D constrained box studies (e.g., Emmerson et al., 2007, and other papers this issue) and global models (e.g., Cook et al., 2007, and other papers this issue). Model runs were carried out for 8-day periods to achieve a nearly steady diurnal cycle, with all model-data comparisons being made using output from the last day. The model was initialised using average measured midnight concentrations, however the results are insensitive to the initial conditions. Isoprene chemistry follows the MIM2 scheme (Taraborrelli et al., 2009) and monoterpene chemistry is split equally between the $\alpha$-pinene (Jenkin, 1996) and d-limonene (Stockwell et al., 1997) schemes, representing the approximately equal split between more- and less-reactive monoterpenes seen in GC-FID measurements at Bukit Atur. The average diurnal temperature variation measured at Bukit Atur is used. Photon fluxes are calculated using the on-line photolysis scheme (Wild et al., 1996). As no direct measurements of cloud cover were made, model cloud cover is adjusted such that the generated diurnal variation of the photolysis frequency of ozone to form excited oxygen atoms, $\mathrm{J}\left(\mathrm{O}^{1} \mathrm{D}\right)$, fits the average measured by a filter radiometer at the site. With this adjusted cloud cover the model reproduces the measured photolysis frequency of $\mathrm{NO}_{2}$ well, leading to the conclusion that photolysis rates are effectively simulated across the wavelength band of interest for boundary layer photochemistry.

Surface emissions of BVOCs, $\mathrm{NO}, \mathrm{CO}$ and $\mathrm{CH}_{4}$ were emitted into the box at each timestep and are assumed to be mixed instantaneously throughout the box. $\mathrm{CH}_{4}$ and $\mathrm{CO}$ are emitted following Ohara et al. (2007), whilst BVOC and NO emissions are described in Sect. 4. All mentions in this paper of emissions into the model refer to above-canopy emissions. Studies of of in-canopy chemistry (Fuentes et al., 2007; Farmer and Cohen, 2008) have indicated that some oxidation of BVOCs may occur within the canopy, resulting in a net emission of oxidation products above the canopy. These studies show that the photolytic source of $\mathrm{OH}$ is substantially reduced within the canopy due to the reduced photolytic flux density and hence oxidation by ozone and/or $\mathrm{NO}_{3}$ becomes important. Farmer and Cohen (2008) infer very high levels of $\mathrm{OH}$ in the canopy of a pine forest which they attribute to the ozonolysis of very reactive organic compounds emitted within the canopy, such as those implied by Holzinger et al. (2005). However the forest in which these measurements were conducted experiences high levels of ozone, with Murphy et al. (2007) finding average 8 hour maximum ozone mixing ratios $>60 \mathrm{ppbv}$. This is compared to the very low ozone (4-8 ppbv) mixing ratios measured within at the OP3 in-canopy site. Likewise the study of Fuentes et al. (2007) reports significant oxidation by $\mathrm{NO}_{3}$, which is unlikely during OP3 due to the low $\left[\mathrm{NO}_{\mathrm{x}}\right]$ observed. In another modelling study over tropical rainforest Ganzeveld et al. (2008) calculate that about $90 \%$ of their modelled isoprene flux exits the rainforest canopy. The missing $10 \%$ is not all reacted, with soil uptake also playing a role (Cleveland and Yavitt, 1997; Pegoraro et al., 2006). Given that oxidation products themselves may be deposited before exiting the canopy, the above canopy-flux of oxidation products will be a relatively small proportion of the whole. Hence an explicit coverage of incanopy chemistry is neglected here. 
The box height is defined during the day by the height of the well-mixed PBL, which vertical velocity variance measurements from a pulsed Doppler LIDAR (light detection and ranging) indicate to be $800 \mathrm{~m}$ between 10:00-18:00 LT (Pearson et al., 2010). As measurements of vertical velocity variance are a direct measurement of the turbulent mixing process, they are the most useful data for the estimation of mixing height during convective conditions (Tucker et al., 2009). This estimation of mixing height also agrees closely with that derived from aerosol backscatter, which may be considered an indicator of the vertical extent of mixing. Aircraft profiles over the rainforest during OP3-3 indicated that the region of $d \theta / d h=0$ rarely extended above $1000 \mathrm{~m}$ above ground-level, whilst $\mathrm{NO}_{\mathrm{x}}$ mixing ratios dropped off rapidly above $\sim 800 \mathrm{~m}$. A mixing layer height of $800 \mathrm{~m}$ is significantly less than the 1200-1500 m indicated in some studies of the Amazon (Martin et al., 1988; Krejci et al., 2005; Eerdekens et al., 2009). However it is comparable with the measurements of Fisch et al. (2004) who measured a mean maximum convective boundary layer height of $1002 \mathrm{~m}$ (standard deviation $195 \mathrm{~m}$ ) during the Amazonian wet season, using sonde profiles. The specification of wet season is important as the 1200-1500-m measurements were all made in the dry season when boundary layer heights have been observed to be higher than in the wet season (Fisch et al., 2004). As OP3 typically experienced daily rainfall episodes, a comparison against measurements made during the Amazonian wet season is most appropriate.

Upon collapse of the well-mixed boundary layer at 18:00 LT, the box is split into two separate layers, the lower one representing the inversion-capped nocturnal boundary layer (NBL), and the upper one representing the residual layer. These layers are integrated separately throughout the night with no mixing between them. When LIDAR measurements show turbulent mixing to be re-initiated between 08:00-10:00 LT the following morning (Pearson et al., 2010), the residual layer concentrations are gradually mixed into the lower box as the mixing height rises, until the lower box has engulfed the residual layer, following the parametrisation,

$$
\begin{aligned}
& C_{\mathrm{L}}(i, t)=C_{\mathrm{U}}(i, t-1)+ \\
& \left(\left(C_{\mathrm{U}}(i, t-1)-C_{\mathrm{L}}(i, t-1)\right) \times \frac{m(t)}{h(t)} \times T\right)
\end{aligned}
$$

where $C_{\mathrm{L}}$ and $C_{\mathrm{U}}$ are the concentrations of species $i$ at time $t$ in the lower and upper box respectively, $h$ is the mixing height (height of the lower box), $m$ is the rate of mixing height rise and $T$ is the model timestep. In the absence of reliable measurements, the nighttime PBL height is set at $200 \mathrm{~m}$ following sensitivity studies of the measurement fit. The aim of this optimisation is to gain the best fit to the daytime measurements and therefore comparisons of the modelled nighttime concentrations to the measurements should be made with caution, especially for the lower box. No other mixing or entrainment processes are permitted.
Dry deposition is included for $\mathrm{O}_{3}, \mathrm{NO}_{\mathrm{x}}, \mathrm{N}_{2} \mathrm{O}_{5}, \mathrm{HNO}_{3}$, $\mathrm{HO}_{2} \mathrm{NO}_{2}, \mathrm{H}_{2} \mathrm{O}_{2}, \mathrm{HCHO}, \mathrm{CH}_{3} \mathrm{CHO}, \mathrm{CH}_{3} \mathrm{OOH}, \mathrm{CH}_{3} \mathrm{CO}_{3} \mathrm{H}$, PANs and isoprene nitrates using the values listed in Evans et al. (2000). The deposition velocity for isoprene nitrates is assumed to be as for $\mathrm{HNO}_{3}$ following Horowitz et al. (2007). Wet deposition is considered in Sect. 5.2.

\section{Emissions optimisation}

Hewitt et al. (2010) report an average midday $\mathrm{NO}_{\mathrm{x}}$ mixing ratio of 200 pptv. In such a remote $\mathrm{NO}_{\mathrm{x}}$-limited regime, accurate emissions of $\mathrm{NO}$ are vital to effective modelling. However above-canopy measurements of NO fluxes at Bukit Atur are not available. Therefore it is necessary to make an estimate of the above-canopy emission from the available ambient concentration data. This estimation process was also used to estimate isoprene and total monoterpene fluxes, as a cross-check. A tri-variate sensitivity study of 384 runs was carried out, varying 24-h average NO emissions from 0.002 to $0.008 \mathrm{mg} \mathrm{N} \mathrm{m}^{-2} \mathrm{~h}^{-1}$ and monoterpene and isoprene emissions from 0.06 to 0.24 and 0.14 to $0.37 \mathrm{mg} \mathrm{m}^{-2} \mathrm{~h}^{-1}$ respectively. The selection of these ranges was informed by previous coarser resolution sensitivity studies, covering a much wider range of values. The isoprene emission followed a diurnal cycle defined by its characteristic light dependence (Guenther et al., 2006). Monoterpene emission was set to follow a the same diurnal cycle as isoprene, following the findings of Kuhn et al. (2004) and the OP3 measurements, which also suggested very little monoterpene emission during the night. A cost function was then run over the model output to locate the optimum emission fluxes that replicate the concentrations observed in the field. The cost function uses OP3-1 campaign-median values for each hour of a 24h cycle for $\mathrm{OH}, \mathrm{NO}, \mathrm{NO}_{2}, \mathrm{O}_{3}$, isoprene, monoterpenes and $\mathrm{HO}_{2}+\mathrm{RO}_{2}$, in the form,

$C_{\text {total }}=\sum_{t=10}^{t=18} \sum_{i=1}^{n}\left(w(i) \frac{\left|x_{i}(t)-\hat{x}_{i}(t)\right|}{\hat{x}_{i}(t)}\right)$

where $C_{\text {total }}$ is the total cost, a dimensionless metric where small numbers indicate a better fit, $t$ is the hour of the day, $n$ is the number of species used in the fitting, $\hat{x}_{i}$ is the campaign median measured concentration of a species for each hour of the day and $x_{i}$ is the modelled concentration of that species, $w$ is a weighting function for that species (typically $w=1$ ). Only 10:00-18:00 LT concentrations were used, as LIDAR measurements give confidence that the flux tower is fully enveloped by the PBL during that period, and hence the well-mixed assumption of the model is valid. Median values are selected to represent the "typical" day, and eliminate the influence of extreme events. To reflect the fact that the $\mathrm{OH}$ and $\mathrm{HO}_{2}+\mathrm{RO}_{2}$ measurements may carry more uncertainty, the function was also run with $w=0.5$ for these species. The result returned was virtually identical, indicating a robust fit with respect to the observations. 
The best-fit cost function result of $C_{\text {total }}=2.20$ was found at a 24-h-average monoterpene emission of $0.15 \mathrm{mg} \mathrm{m}^{-2} \mathrm{~h}^{-1}$, isoprene emission of $0.23 \mathrm{mg} \mathrm{m}^{-2} \mathrm{~h}^{-1}$ and $\mathrm{NO}$ emission of $0.005 \mathrm{mg} \mathrm{N} \mathrm{m}^{-2} \mathrm{~h}^{-1}$. It can been seen from Fig. 1 that the region of values below $C_{\text {total }}=2.3$ (coloured dark blue) is quite broad. The best fit is located at the furthest-right point of this dark blue area (black dot in Fig. 1), however this quite broad general minima indicates that monoterpene emissions can be traded on an approximately 1:1 basis for isoprene emissions for only a small penalty in fit. This is not altogether surprising given the broadly comparable atmospheric chemistry and lifetimes of these species, at least as far as the model is concerned. It was not possible to use observations of methacrolein (MACR) or methyl-vinyl ketone (MVK), which are oxidation products unique to isoprene, to distinguish between isoprene and monoterpene chemistry, as the strong model overestimation of MACR and MVK (see Sect. 5), suggests these products are not being treated correctly in the model.

The best-fit isoprene and monoterpene emissions show excellent agreement with the measured eddy-covariance fluxes, following the median measurement very closely throughout the day (Fig. 2). It should be noted that these isoprene emissions are much less than the $1.7 \mathrm{mg} \mathrm{m}^{-2} \mathrm{~h}^{-1}$ predicted for the region by Müller et al. (2008) for the year 2001. The 24$\mathrm{h}$ average measured isoprene (monoterpene) emission for the "typical" day was $0.28(0.19) \mathrm{mg} \mathrm{m}^{-2} \mathrm{~h}^{-1}$ (Langford et al., 2010). The model-data agreement gives confidence in the estimated NO emission. It also suggests that this method may be useful in estimating emissions in other campaigns where flux measurements are not available, assuming the the local chemistry and mixing is adequately understood. As the model generated fluxes can only account for what remains or is reacted in the boundary layer, it is possible that much of the $18 \%$ difference between model estimated and measured emissions may be explained by venting to the free troposphere. If venting out of the top of the boundary layer is occurring, then comparisons against the eddy-covariance fluxes, which measure the total flux from the surface, only necessitate that the model generated net flux into the PBL be less.

The model-estimated above-canopy NO emission compares very well with the yearly average above-canopy flux estimate of $0.005 \mathrm{mg} \mathrm{N} \mathrm{m}^{-2} \mathrm{~h}^{-1}$ given for the area in April by the Yienger and Levy (1995) database. Monthly values in this database range from 0.002 in February to $0.012 \mathrm{mg} \mathrm{N} \mathrm{m}^{-2} \mathrm{~h}^{-1}$ in July. Given the minimal variability of the seasonal climate cycle in Borneo (Chappell et al., 2001; Hewitt et al., 2010) these minima and maxima nicely bracket the estimated emission. Anthropogenic contributions to the local $\mathrm{NO}_{\mathrm{x}}$ budget are small in comparison to soil $\mathrm{NO}_{\mathrm{x}}$ in this very remote location.

However, the model-estimated NO emission is 26 times smaller than the soil flux of $0.13 \mathrm{mg} \mathrm{N} \mathrm{m}^{-2} \mathrm{~h}^{-1}$ (J. Dorsey, personal communication, 2009) measured via the chamber

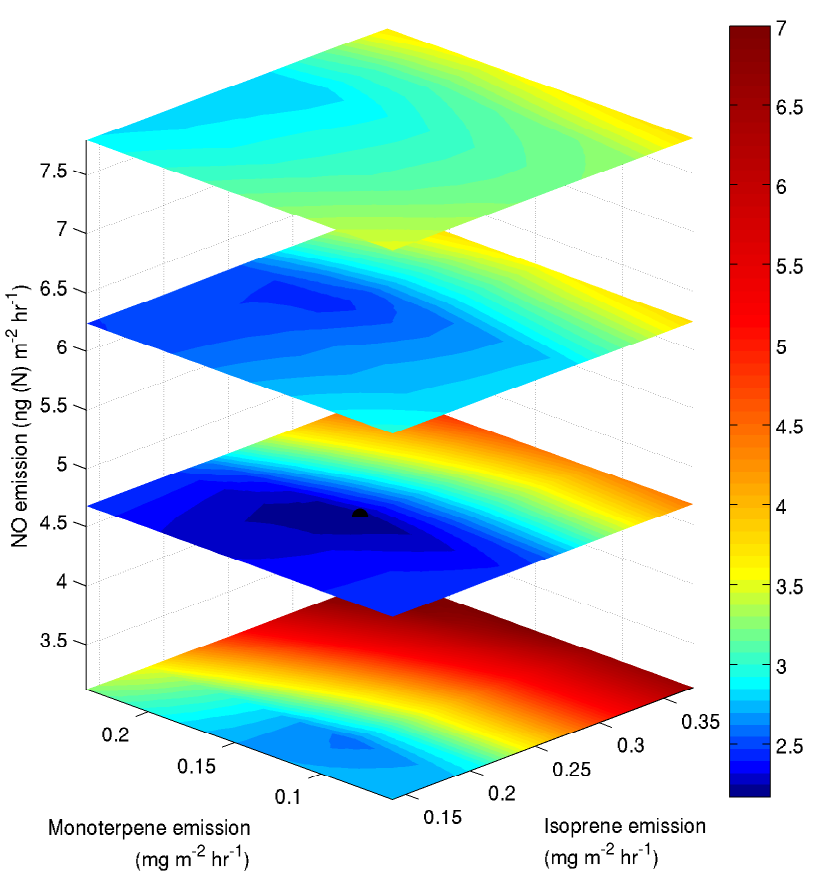

Fig. 1. Cost function surface generated to find the optimum emissions of isoprene, monoterpenes and $\mathrm{NO}$ to fit measurements of $\mathrm{OH}$, $\mathrm{NO}, \mathrm{NO}_{2}, \mathrm{O}_{3}$, isoprene, monoterpenes and $\mathrm{HO}_{2}+\mathrm{RO}_{2}$. Lower values indicate a better fit, with the minima marked by a black dot.

method (van Dijk and Duyzer, 1999) at a nearby undercanopy site $\left(4^{\circ} 58^{\prime} 50^{\prime \prime} \mathrm{N}, 117^{\circ} 51^{\prime} 19^{\prime \prime} \mathrm{E}\right)$. As the PBL can be considered well-mixed during the day, then the model estimate may be considered to be representative of the abovecanopy NO flux over a fairly large locality. The difference between the model estimate and under-canopy measurements is $96 \%$, compared to the $75 \%$ and $50 \%$ canopy reduction estimated for tropical rainforest by Yienger and Levy (1995) and Ganzeveld et al. (2002) respectively.

To test the impact of higher NO fluxes, the model was run with the measured soil $\mathrm{NO}_{\mathrm{x}}$ emissions, using a canopy reduction of $75 \%$. This resulted in a $400 \%$ overestimation of midday $\left[\mathrm{NO}_{2}\right]$ and $180 \%$ overestimation of [NO] compared to the measurements. Furthermore $\mathrm{NO}_{\mathrm{y}}$ mixing ratios were hugely overestimated at greater than 2 ppbv. Such high emissions exiting the canopy are clearly not consistent with the measurements, unless some very large loss of $\mathrm{NO}_{\mathrm{y}}$ is not accounted for in the model. Possible losses of $\mathrm{NO}_{\mathrm{y}}$ are tested below.

Probably the most poorly understood $\mathrm{NO}_{\mathrm{y}}$ loss in this scenario is via organic nitrates, particularly isoprene nitrates. However the $10 \%$ average alkyl nitrate yield in the MIM2 mechanism from the $\mathrm{RO}_{2}+\mathrm{NO}$ reaction (Taraborrelli et al., 2009 ), is already at the high end of the spectrum of $4-12 \%$ suggested in the literature (Carter and Atkinson, 1996; Chen et al., 1998; Sprengnether et al., 2002; Paulot et al., 2009). 

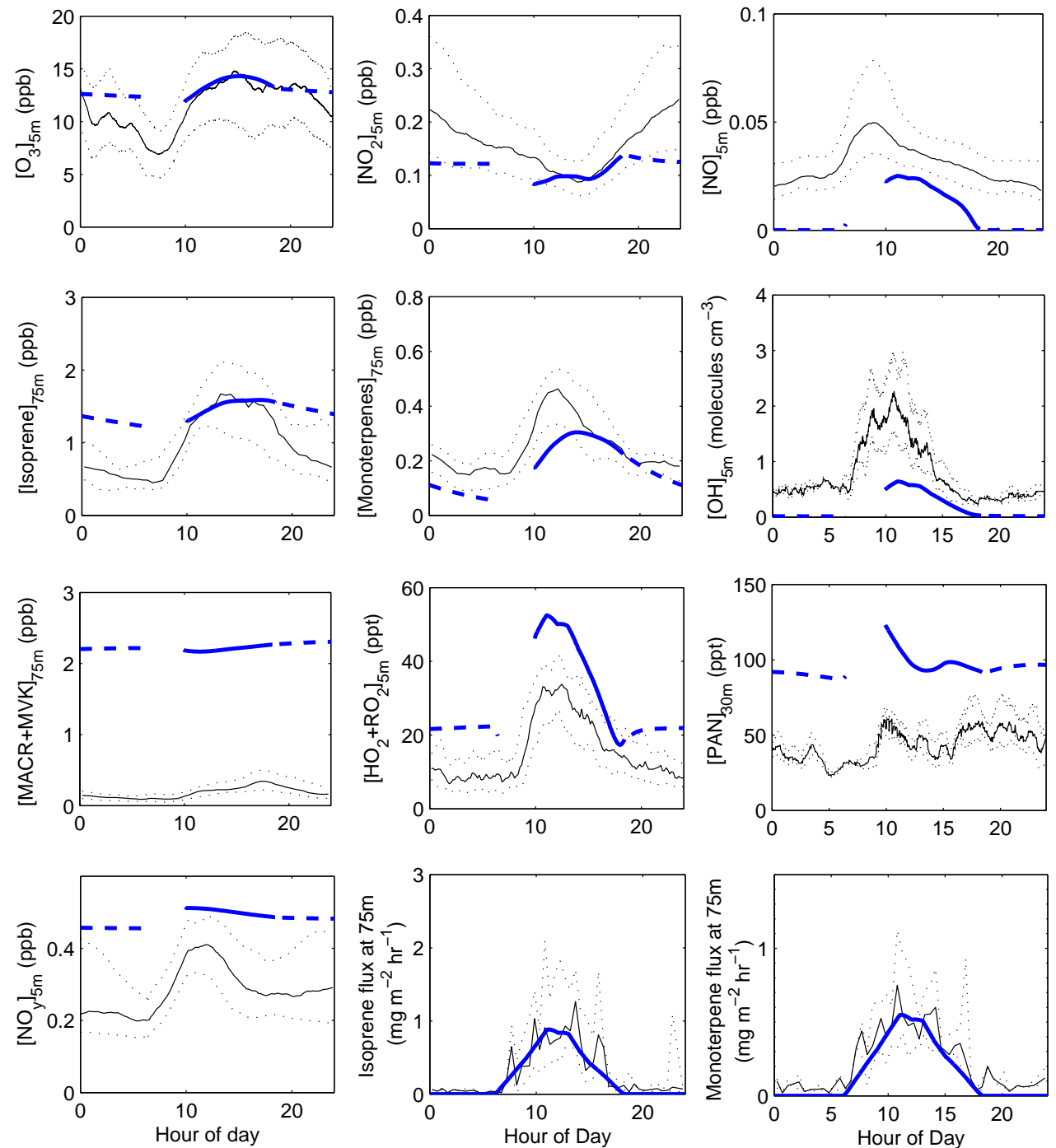

Fig. 2. Comparison of model best fits (blue line) against the OP3-1 average measurement at Bukit Atur (black line). Upper and lower quartiles for the measurements are marked by grey dots. Measurement height is shown in subscript. The solid blue line represents the wellmixed daytime box, whilst the dashed line shows the nighttime residual layer concentrations. The discontinuity between 08:00 and 10:00 LT is due to the mixing between the two layers during this period.

Furthermore the dry deposition velocity applied here to the isoprene nitrates is at the upper end of the range suggested in the literature $\left(0.4-5 \mathrm{~cm} \mathrm{~s}^{-1}\right.$, Shepson et al., 1996; Rosen et al., 2004; Giacopelli et al., 2005; Horii et al., 2006). Hence the recycling of isoprene nitrates back into $\mathrm{NO}_{\mathrm{x}}$ is small. The $\mathrm{NO}_{3}+$ isoprene $\rightarrow$ alkyl nitrate channel can be neglected due to the very low levels of $\mathrm{NO}_{\mathrm{x}}$ and hence $\mathrm{NO}_{3}$ during OP3. Treves et al. (2000) have shown hydroxy alkyl nitrates, similar to those formed from isoprene, to be very soluble, with Henry's Law constants equal to $1.7 \times 10^{4} \mathrm{M} \mathrm{atm}^{-1}$ at $298 \mathrm{~K}$. Therefore the model is run with wet deposition enabled. Although the reduction in modelled afternoon $\left[\mathrm{NO}_{\mathrm{y}}\right]$ is striking, at its minimum value it is still more than twice the mea- surements. Furthermore, $\mathrm{NO}_{\mathrm{x}}$ concentrations are barely altered. For details on the wet deposition parametrisation see Sect. 5.2.

Another possibility is that increased PAN deposition, as observed by Turnipseed et al. (2006), could draw more $\mathrm{NO}_{\mathrm{x}}$ through PAN formation to maintain equilibrium as the PAN is deposited. To test this the model is run with $V_{\mathrm{d}(\mathrm{PAN})}=1.0 \mathrm{~cm} \mathrm{~s}^{-1}$ and $V_{\mathrm{d}(\text { higherPAN })}=1.5 \mathrm{~cm}^{-1}$ following the average maximum observed by Turnipseed et al. (2006). $\mathrm{NO}_{\mathrm{y}}$ concentration is indeed reduced, however the reduction of $16 \%$ is nowhere near sufficient for the modelled concentrations to approach the measurements. In another test $V_{\mathrm{d}\left(\mathrm{HNO}_{3}\right)}$ is increased to $5.0 \mathrm{~cm} \mathrm{~s}^{-1}$, the very upper 
end of the literature range. This also results in a $16 \%$ reduction in $\left[\mathrm{NO}_{\mathrm{y}}\right]$, but virtually no change in $\left[\mathrm{NO}_{\mathrm{x}}\right]$. Finally the $\mathrm{NO}_{2}$ deposition velocity is doubled to give maximum $V_{\mathrm{d}\left(\mathrm{NO}_{2}\right)}=1.0 \mathrm{~cm} \mathrm{~s}^{-1}$. Only a $7 \%$ decrease in $\left[\mathrm{NO}_{\mathrm{y}}\right]$ is achieved.

Even combining all these processes in a single run leaves the minimum in modelled $\left[\mathrm{NO}_{\mathrm{y}}\right]$ almost twice the measured value, and the concentrations in the morning, before substantial rainfall, are highly unrealistic. Modelled $\mathrm{NO}_{2}$ and NO concentrations remain overestimated by $320 \%$ and $180 \%$ respectively. Assuming that there is no canopy loss unaccounted for in the studies of Yienger and Levy (1995) and Ganzeveld et al. (2002), there are three factors which could explain the difference between measured and modelled $\left[\mathrm{NO}_{\mathrm{x}}\right]$ fluxes. Firstly, the measurements of $\mathrm{NO}_{\mathrm{x}}$ which the model is constrained against, were made $5 \mathrm{~m}$ above grass in a rainforest clearing. It is possible that the soil in the clearing will have a different characteristic $\mathrm{NO}$ emission to the surrounding rainforest. However, as explained in Sect. 2, comparison of 5-m and aircraft measurements supports the hypothesis that the measured $5-\mathrm{m}\left[\mathrm{NO}_{\mathrm{x}}\right]$ was representative of the mixed boundary layer during the day. Hence this possibility is discarded. Second, it is possible that a significant amount of $\mathrm{NO}_{\mathrm{x}}$ is lost from the boundary layer by entrainment into the free troposphere. However dilution on this scale would have a very large impact on concentrations of other tracers such as isoprene, which are modelled well without an entrainment factor. Finally, natural soils demonstrate considerable heterogeneities. Measured soil emissions between the chambers varied by more than an order of magnitude. Hence attempting to scale up such values is fraught with error as the heterogeneity of the soil at the canopy scale cannot be accurately determined.

\section{Comparison of best-fit model concentrations with measurements}

A comparison of the output generated by running the model with the emissions defined in Sect. 4, against the in-situ measurements made at Bukit Atur during OP3-1, is shown in Fig. 2. As mentioned in Sect. 4, due to the nighttime meteorology, the comparison is most valid between 10:0018:00 LT, hence concentrations from the surface box are only shown between these times. Concentrations modelled in the nighttime residual layer (dashed blue line) are also shown for context, although direct comparison should not be made between modelled residual layer concentrations and 5-m level measurements. No concentrations are shown between 08:0010:00 LT as the concentrations observed at this point will depend strongly on the height of the observer in the boundary layer. Table 1 lists the individual contributions, $C_{i}$, to the total cost, $C_{\text {total }}$, between 10:00-18:00 LT. It also lists the mean-bias error (MBE) as a percentage of the average 10:00-18:00 LT concentration. This statistic gives the aver-
Table 1. Individual contributions, $C_{i}$, to the total cost, $C_{\text {total }}$, and $\%$ mean-bias error (MBE), between 10:00-18:00 LT for the best fit scenario generated in Sect. 4.

\begin{tabular}{lccr}
\hline Species & $C_{i}$ & $\%$ of $C_{\text {total }}$ & $\% \mathrm{MBE}$ \\
\hline $\mathrm{NO}$ & 0.48 & 22 & -48 \\
$\mathrm{NO}_{2}$ & 0.13 & 6 & -10 \\
$\mathrm{O}_{3}$ & 0.05 & 2 & +5 \\
$\mathrm{OH}$ & 0.64 & 29 & -64 \\
$\mathrm{HO}_{2}+\mathrm{RO}_{2}$ & 0.59 & 27 & +58 \\
Isoprene & 0.08 & 4 & +5 \\
Total monoterpenes & 0.24 & 11 & -24 \\
\hline Total & 2.20 & 100 & \\
\hline
\end{tabular}

age percentage by which the model under- or over-predicts the measurements. It is calculated using Eq. (2), but without taking the absolute value of the numerator.

Good agreement in particular is seen for $\mathrm{O}_{3}$, and $\mathrm{NO}_{2}$ with MBEs of $+5 \%$ and $-10 \%$ respectively. This robust fit to $\mathrm{O}_{3}$ and $\mathrm{NO}_{\mathrm{x}}$ was also observed by Pike et al. (2009). The relatively poor fit of $\mathrm{NO}$ compared to the other two variables is attributable to the overestimation of peroxy radical concentrations (MBE of $+58 \%$ ). The interaction of peroxy radicals and $\mathrm{NO}$ control the cycling of $\mathrm{NO}$ to $\mathrm{NO}_{2}$ and $\mathrm{HO}_{2}$ to $\mathrm{OH}$ via Reaction (R1), as well as conversion of $\mathrm{RO}_{2}$ to $\mathrm{HO}_{2}$.

$\mathrm{HO}_{2}+\mathrm{NO} \rightarrow \mathrm{OH}+\mathrm{NO}_{2}$

As discussed in Sect. 5.2, when wet deposition is turned on, modelled peroxy radical concentrations come into close agreement with the measurements. Consequently the simulated $[\mathrm{NO}]$ increases to within the bounds of the observations, due to a decrease in the rate of cycling of $\mathrm{NO}$ to $\mathrm{NO}_{2}$ via Reaction (R1). Conversely, constraining daytime [NO] to the measurements results in a serious deterioration of the fit to $\mathrm{NO}_{2}, \mathrm{NO}_{\mathrm{y}}$ and $\mathrm{O}_{3}$ concentrations. $\mathrm{NO}_{\mathrm{y}}$ concentrations are overestimated in the model. As mentioned in Sect. 4, wet deposition can play a role for many $\mathrm{NO}_{\mathrm{y}}$ species, and indeed later analysis including the effects of wet deposition (see e.g. Fig. 6) yields concentrations close to the measurements. The behaviour of $\mathrm{O}_{3}, \mathrm{NO}$ and $\mathrm{NO}_{2}$ during the night will be the focus of a subsequent paper (Pugh et al., 2010).

Modelled $\mathrm{OH}$ concentrations are around 2-3 times less than those measured with an MBE of $-64 \%$. As HONO photolysis has been observed to contribute as much as $56 \%$ of $\mathrm{OH}$ production in some forested environments (Kleffmann, 2007), it appears possible that a model underestimation of HONO could explain the missing $\mathrm{OH}$. However measurements of HONO during OP3-3 indicate mixing ratios $<10 \mathrm{pptv}$. At a midday HONO photolysis rate of $8.7 \times 10^{-4} \mathrm{~s}^{-1}$, as calculated by CiTTyCAT, $10 \mathrm{pptv}$ of HONO would generate $2.0 \times 10^{5}$ molecules $\mathrm{OH} \mathrm{cm}^{-3} \mathrm{~s}^{-1}$, $\sim 3 \%$ of the modelled $\mathrm{OH}$ source at that time. This 
demonstrates that HONO photolysis was not important during OP3-3, although it is possible that HONO concentrations were higher during the OP3-1 period upon which our model analysis is based. This will be investigated further by Whalley et al. (2010b).

Analysis of modelled $\mathrm{OH}$ loss mechanisms concludes that $70 \%$ of $\mathrm{OH}$ loss at midday is attributable to isoprene or its direct oxidation products, with a further $11 \%$ due to monoterpenes and their oxidation products. Constraining the model to measured daytime $\mathrm{OH}$ concentrations results in a strong increase in peroxy radical concentrations to more than twice the measured values, whilst decreasing $[\mathrm{NO}]$ and $\left[\mathrm{NO}_{2}\right]$. Interestingly the concentration of $\mathrm{HO}_{2}$ is insensitive to the model being constrained to $\mathrm{OH}$. Hence the increase in total peroxy radicals is due to $\mathrm{RO}_{2}$ from the increased oxidation of VOC under the higher $[\mathrm{OH}]$ conditions. Given the constraints on emission fluxes provided by measurements, it appears something may be amiss within the isoprene oxidation scheme, as hypothesised by Lelieveld et al. (2008). This possibility will be explored in more detail in Sect. 6. Morning monoterpene concentrations are somewhat underestimated by the model. The reason for this is not entirely clear, but may be due to uncertainty in the speciation of monoterpenes at the canopy level, meaning the split between monoterpene schemes used here may not be ideal. Routing monoterpene concentrations entirely though the $\alpha$-pinene or d-limonene schemes results in changes of $+14 \%$ and $-15 \%$ respectively.

During the night, modelled residual layer concentrations of $\mathrm{HO}_{2}+\mathrm{RO}_{2}$ are 2-3 times larger than measured at $5 \mathrm{~m}$, suggesting that something is depleting peroxy radical concentrations near the surface during the night. It is likely that this is linked to the relatively high nighttime $[\mathrm{NO}]$ at $5 \mathrm{~m}$, which would react with $\mathrm{HO}_{2}$ and $\mathrm{RO}_{2}$, leading to the formation of the relatively high nocturnal $[\mathrm{OH}]$ observed at $5 \mathrm{~m}$ (see e.g., Geyer and Stutz, 2004). Further discussion of this issue is beyond the scope of this paper, but will be addressed in Whalley et al. (2010a).

\subsection{Dry deposition of MACR and MVK}

Whilst daytime modelled isoprene and monoterpene concentrations are quite close to the measurements, there is a substantial overestimation, by 5-10 times, of modelled MACR and MVK concentrations, compared to the measurements. This is much larger than the measurement uncertainty of a factor of two. As these products are principally formed through the reaction of $\mathrm{OH}+$ isoprene, this lends further credence to the idea that something may be wrong with the way isoprene oxidation is represented. Indeed Peeters et al. (2009) suggest that current yield for the reaction of isoprene peroxy radicals with NO may produce $50 \%$ too much MACR and MVK in these low $\left[\mathrm{NO}_{\mathrm{x}}\right]$ conditions. However, this alone cannot account for the overestimation seen. Such large overestimations are not apparent in other oxidation products, such as $\mathrm{HO}_{2}+\mathrm{RO}_{2}$ or PAN (Fig. 2).
Another possibility is that MACR and/or MVK undergoes significant dry deposition. The existence of a substantial dry deposition flux of MACR/MVK has been suggested before by Karl et al. (2004), following measurements made in Costa Rica. Using eddy-covariance measurements and taking account for the effects of chemistry and dew, they measure an average deposition velocity $\left(V_{\mathrm{d}(\mathrm{MACR}+\mathrm{MVK})}\right)$ of $1.6 \mathrm{~cm} \mathrm{~s}^{-1}$. However, they also calculate a possible deposition velocity over the Amazon of $2-4 \mathrm{~cm} \mathrm{~s}^{-1}$ utilising data published by Andreae and Merlet (2001). More recently, measurements during the AMAZE field study indicated $V_{\mathrm{d}(\mathrm{MACR}+\mathrm{MVK})}=2.4 \mathrm{~cm} \mathrm{~s}^{-1}$ (Karl et al., 2009b), and measurements made over a strongly isoprene emitting oil palm plantation during OP3-2 showed $V_{\mathrm{d}(\mathrm{MACR}+\mathrm{MVK})}=1-$ $2 \mathrm{~cm} \mathrm{~s}^{-1}$ (Misztal et al., 2010)

Such high deposition rates cannot be explained by current theory. For instance, Zhang et al. (2002) estimate daytime deposition velocities over evergreen deciduous forest of 0.341 and $0.499 \mathrm{~cm} \mathrm{~s}^{-1}$ for MACR and MVK respectively, using a dry deposition model calibrated using measurements of $\mathrm{O}_{3}$ and $\mathrm{SO}_{2}$. However they note that very little data is available to evaluate these values. Interestingly Zhang et al. (2002) also predict deposition velocities for PAN species $\sim 0.5 \mathrm{~cm} \mathrm{~s}^{-1}$, whereas recent measurements by Turnipseed et al. (2006) showed deposition of PAN species up to $1.5 \mathrm{~cm} \mathrm{~s}^{-1}$. In a recent modelling study Ganzeveld et al. (2008), using a similar approach to estimating dry deposition velocities to Zhang et al. (2002), overestimate MACR+MVK by 2-3 times compared to concentrations measured over Suriname during the GABRIEL campaign. Such a range of literature values illustrates that MACR and MVK deposition rates are currently poorly characterised, yet they may be large enough to significantly impact upon concentrations.

To test the importance of MACR/MVK deposition for the Danum Valley regime, a model run was carried out with $V_{\mathrm{d}(\mathrm{MACR}+\mathrm{MVK})}=2.0 \mathrm{~cm} \mathrm{~s}^{-1}$. This deposition velocity can explain much of the difference between the model and measurements, causing a $63 \%$ reduction in midday mixing ratio to $0.8 \mathrm{ppbv}$, about twice the magnitude measured. MACR/MVK flux measurements over the rainforest show no clear net flux. However, it is quite likely that any dry deposition flux is masked in the measurements due to the spatial variation of MACR and MVK chemical sources and sinks within the PBL.

The above dry deposition of MACR and MVK decreases the $\mathrm{OH}$ sink, increasing modelled peak $[\mathrm{OH}]$ by $18 \%$ to $7.5 \times 10^{6}$ molecules $\mathrm{cm}^{-3}$. This increase in $[\mathrm{OH}]$ in turn increases modelled isoprene and monoterpene loss rates, hence decreasing their concentrations significantly below measurements. Re-computing a new best-fit then increases isoprene and monoterpene emissions, in order to maintain a fit to observed isoprene and monoterpene concentrations, consequently reducing $[\mathrm{OH}]$ back to similar levels to those in Fig. 2. This illustrates the importance of correctly characterising MACR/MVK deposition velocities to simulating PBL 
chemistry, and raises the possibility that deposition of other important intermediate species might lead to significant errors in model studies.

\subsection{Wet deposition}

The model runs above also show a large build-up of organic peroxides $(\mathrm{ROOH})$ to $>5 \mathrm{ppbv}$ over the 8 day period, These are produced as part of isoprene oxidation, typically by the reaction of organic peroxy radicals $\left(\mathrm{RO}_{2}\right)$ with the hydrogen peroxy radical $\left(\mathrm{HO}_{2}\right)$. Some of these higher peroxides have reaction rates with $\mathrm{OH}$ similar to that of isoprene with $\mathrm{OH}\left(\sim 10^{-10} \mathrm{~cm}^{3}\right.$ molecule $\left.{ }^{-1} \mathrm{~s}^{-1}\right)$ and hence may contribute substantially to the $\mathrm{OH}$ sink. However organic peroxides typically have high Henry's Law coefficients $>1 \times 10^{6} \mathrm{M} \mathrm{atm}^{-1}$, and hence are very susceptible to wet deposition processes.

In this study wet deposition has been simulated using the S-WET2 scheme described in Real et al. (2008). This scheme has been extended to cover all appropriate species in the organic schemes used here. Henry's Law constants have been taken from Sander (2009) and Treves et al. (2000) where available. For those species lacking a measured value for Henry's Law, the most structurally similar compound with available measurements has been utilised. The $\mathrm{pH}$ of rainwater in this remote region is assumed to be 5.6. Notable species aside from $\mathrm{ROOH}$ which undergo wet deposition in the scheme are $\mathrm{HCHO}, \mathrm{HO}_{2}, \mathrm{H}_{2} \mathrm{O}_{2}, \mathrm{HNO}_{3}, \mathrm{HO}_{2} \mathrm{NO}_{2}$, CHO$\mathrm{CHO}, \mathrm{CH}_{3} \mathrm{CHO}$ and isoprene nitrates. The rain rates supplied to the model are the diurnal averages of those measured at Danum Valley Field Centre $\left(4^{\circ} 57^{\prime} 42^{\prime \prime} \mathrm{N} 117^{\circ} 48^{\prime} 12^{\prime \prime} \mathrm{E}\right)$ during the course of OP3-1. This profile gives no rain during the morning, but a strong peak of $\sim 3 \mathrm{~mm} \mathrm{~h}^{-1}$ at 15:00 LT, with levels circa $0.5 \mathrm{~mm} \mathrm{~h}^{-1}$ persisting throughout the afternoon and evening. All rainfall is assumed to be convective.

Applying this wet deposition parametrisation to the model run shown in Fig. 2 leads to an $88 \%$ reduction in modelled midday $[\mathrm{ROOH}]$ to $\sim 0.7 \mathrm{ppbv}$. This is much closer to aircraft measurements made during OP3-3 of $\sim 0.2$ ppbv. Furthermore the tendency of ROOH to accumulate in the box is greatly reduced. Peak HCHO mixing ratios are reduced from $\sim 4$ ppbv to $\sim 1.5 \mathrm{ppbv}$, with almost no HCHO persisting in the afternoon. Clearly wet deposition is a very important loss process for several BVOC oxidation products in this environment.

The photolysis of $\mathrm{HCHO}$ is an important source of $\mathrm{HO}_{2}$, so a reduction in $\mathrm{HCHO}$ concentrations will play a role in the $25 \%$ reduction in modelled peroxy radical concentrations yielding a negative impact on $\mathrm{OH}$ production. However, overall, the change in the $\mathrm{OH}$ sink cancels out this decrease in production. Closer inspection reveals that the wet deposition of $\mathrm{NO}_{\mathrm{y}}$, in particular isoprene nitrates, leads to a substantial reduction in ambient $\left[\mathrm{NO}_{\mathrm{x}}\right]$. When the $\mathrm{NO}$ emission is increased to cancel out this effect the decrease in $\left[\mathrm{HO}_{2}+\mathrm{RO}_{2}\right]$ is almost unchanged, but an increase in peak $[\mathrm{OH}]$ of $72 \%$ is revealed with a consequent decrease in peak isoprene con- centration of $31 \%$, showing that when $\left[\mathrm{NO}_{\mathrm{x}}\right]$ is maintained the change in $\mathrm{OH}$ sink caused by wet deposition is substantial. Hence consideration of wet deposition is also an important factor in correctly modelling the oxidising capacity of the tropical boundary layer. The importance of correct deposition velocities of intermediates for the $\mathrm{OH}$ sink is also highlighted in Edwards et al. (2010).

\subsection{Residual layer MACR and MVK}

In their paper describing modelling of atmospheric chemistry over rainforest in Guyana and Suriname, Ganzeveld et al. (2008) report a modelled increase in residual layer MACR and MVK concentrations during the night, which they believe was a contributor to their overestimation of the daytime concentrations of these species. Although this study focuses upon daytime measurements for reasons explained in Sect. 3, some analysis of this problem is possible here.

CiTTyCAT also observes a small increase in the upper box MACR and MVK concentrations during the night. The small magnitude is likely due to the lower concentrations of ozone and isoprene during this study cf. Ganzeveld et al. (2008). It is possible, although absolute confirmation cannot be made, that the 75-m observations are within the residual layer during the night. If this is the case, the decrease observed during the night in average total MACR+MVK mixing ratios from $335 \mathrm{pptv}$ at 18:00 LT to $91 \mathrm{pptv}$ at 06:00 LT, suggests the model is incorrectly modelling production and/or loss during the night. Nighttime measurements of isoprene concentration at $75 \mathrm{~m}$ are around $50 \%$ of those modelled in the residual layer. Therefore, if these measurements really are in the residual layer, it is clear that $\sim 50 \%$ too much nighttime production of MACR and MVK is being modelled. Note that this does little to affect the model overestimation of [MACR+MVK] as most of the modelled increase takes place during the day. However, the model overestimation of [MACR+MVK] also means its loss rate to its reaction with ozone is being overestimated many more times than its production. When MACR and MVK concentrations overall are reduced by deposition, the net nighttime production in the residual layer is increased as gross production is virtually unchanged, but loss to ozone is reduced (see Fig. 6).

This lends support to the hypothesis of Ganzeveld et al. (2008) that intermittent nocturnal transport events may be connecting the residual layer with the surface, allowing some deposition from the residual layer. In CiTTyCAT such effects are implicitly accounted for in that by defining the NBL height, which controls deposition rates, by a sensitivity study optimised to daytime concentrations, what is actually defined is an effective NBL height with the aim of producing the correct concentrations at the end of the night. The idea that an optimised NBL height implicitly incorporates mixing with the residual layer has been suggested before by Strong et al. (2009). Indeed, the net change in $[\mathrm{MACR}+\mathrm{MVK}]$ averaged over both boxes during the night 
is negative when $V_{\mathrm{d}(\mathrm{MACR}+\mathrm{MVK})}=1.5 \mathrm{~cm} \mathrm{~s}^{-1}$ is applied. As a box model cannot reproduce the chemical gradients caused by limited mixing in a stable boundary layer, this solution is adequate for the purposes of this study. However, assuming the 75-m nighttime measurements are in the residual layer, it would appear that any model attempting to accurately recreate residual layer concentrations will need to account for such nocturnal transport events.

\section{Isoprene and $\mathrm{OH}$}

The cause of $[\mathrm{OH}]$ underestimation over tropical rainforest is currently unknown, although such model underestimations of $[\mathrm{OH}]$ measurements have been observed before. Tan et al. (2001), measuring over a North American deciduous forest, found that observations of $[\mathrm{OH}]$ were on average 2.7 times greater than the modelled concentrations. However the modelled and measured $\mathrm{HO}_{2}$ were in good agreement. Carslaw et al. (2001) similarly found that modelled $\mathrm{OH}$ concentrations over a forest in Northern Greece were on average, half the measured concentrations. For both these studies observed concentrations of isoprene were $>1 \mathrm{ppbv}$. More recently Ren et al. (2008) found observed [OH] was as much as 4 times larger than modelled $\mathrm{OH}$ in the boundary layer over North America. They also found that higher model underestimation was clearly correlated to increased concentrations of isoprene. In the only other studies to date incorporating $[\mathrm{OH}]$ measurements over a tropical rainforest, Lelieveld et al. (2008) and Martinez et al. (2008) report very much higher observed concentrations of $\mathrm{OH}$ than predicted using their chemical model. A notable feature of all these studies is the low $\left[\mathrm{NO}_{\mathrm{x}}\right]$ observed at the sites, and that the model:measurement discrepancy is greater at lower $\mathrm{NO}_{\mathrm{x}}$. In a different study Thornton et al. (2002) show that they are unable to close their $\mathrm{HO}_{\mathrm{x}}$ budgets at low $\left[\mathrm{NO}_{\mathrm{x}}\right]$ based upon current knowledge.

In contrast urban modelling studies have typically agreed well with, or overestimated $[\mathrm{OH}]$ compared to the measurements (e.g. George et al., 1999; Konrad et al., 2003; Emmerson et al., 2005, 2007), although Emmerson et al. (2005) did find some days when they significantly underpredicted $\mathrm{OH}$ concentrations. Ren et al. (2006) also modelled measured $\mathrm{OH}$ and $\mathrm{HO}_{2}$ concentrations well in a rural environment where isoprene concentrations were typically $<1$ ppbv. Similarly Kanaya et al. (2007) overestimate both $\mathrm{OH}$ and $\mathrm{HO}_{2}$ significantly in a model:measurement comparison for Japanese coniferous forests. Whilst Kanaya et al. (2007) measured 200-400 pptv of monoterpenes, they make no mention of isoprene concentrations, which are typically relatively low for coniferous forests (Guenther et al., 2006).

The above literature supports the hypothesis that the underestimation of $[\mathrm{OH}]$ is related to isoprene, or an unaccounted for compound that is emitted following the same pattern. It has been suggested (e.g. Tan et al., 2001; Karl et al., 2007) that the reaction of terpenes and ozone could produce sufficient $\mathrm{OH}$ to bridge the gap between models and measurements. However Ganzeveld et al. (2008) concluded that this pathway alone could not explain the model deficiencies. Modifying the model here such that each reaction of a terpene with $\mathrm{O}_{3}$ produces one $\mathrm{OH}$ molecule, can only generate $[\mathrm{OH}]$ within the bounds of measurements at terpene emission rates much greater than those of isoprene. This test was carried out utilising the rate constant of the sesquiterpene $\beta$-caryophyllene, which, compared to most monoterpenes, has a very fast reaction with $\mathrm{O}_{3}$ and a relatively slow reaction with $\mathrm{OH}$ (Atkinson and Arey, 2003). Thornton et al. (2002) and Lelieveld et al. (2008) noted that errors in the photochemical rate constants could be responsible, particularly those for the dissociation of higher peroxides. However Kubistin et al. (2008) found no evidence for this.

\subsection{OH recycling}

Several recent studies (Lelieveld et al., 2008; Butler et al., 2008; Kubistin et al., 2008) have noted the apparent correlation between $\mathrm{OH}$ and isoprene concentrations, and hypothesised that, under low- $\mathrm{NO}_{\mathrm{x}}$ conditions, there is an as-yetunknown pathway in the isoprene oxidation process that is responsible for recycling $\mathrm{OH}$. Their suggestion is supported to some extent by the experimental work of Hasson et al. (2004), Jenkin et al. (2007) and Dillon and Crowley (2008), who found that $\mathrm{OH}$ could be produced by the reaction of $\mathrm{HO}_{2}$ with organic peroxy radicals containing a carbonyl group. Following this, Lelieveld et al. (2008) and Butler et al. (2008) utilised an $\mathrm{OH}$ recycling mechanism of,

$\mathrm{ISOPROO}+\mathrm{HO}_{2} \rightarrow \mathrm{ISOPROOH}+\mathrm{nOH}$

where ISOPROO are peroxy radicals formed from the reaction of isoprene with $\mathrm{OH}$, ISOPROOH is the resulting peroxide, and $n$ is the number of $\mathrm{OH}$ produced. Lelieveld et al. (2008) found values of $n=2-4$ gave the best fit to their measurements.

The proposed chemistry behind this recycling hypothesis was tested by modifying the model chemistry scheme following the results of Dillon and Crowley (2008). All reactions of $\mathrm{HO}_{2}$ with carbonyl containing peroxy radicals in the isoprene and monoterpene schemes were altered to include a further reaction channel producing $\mathrm{OH}$. The branching coefficient assigned to the new channel depended on the position of the carbonyl group on the peroxy radical. If the carbonyl group was on the same carbon as the peroxy group a branching coefficient of 0.5 was applied, following the result for $\mathrm{CH}_{3} \mathrm{CO}_{3}$ in Dillon and Crowley (2008). For all other positions of the carbonyl group relative to the peroxy group, a coefficient of 0.15 was applied, following $\mathrm{CH}_{3} \mathrm{C}(\mathrm{O}) \mathrm{CH}_{2} \mathrm{O}_{2}$ in Dillon and Crowley (2008). Non-carbonyl containing peroxy radicals are assumed not to display this reaction channel. Considering this extra source of $\mathrm{OH}$ involving the carbonyl groups 

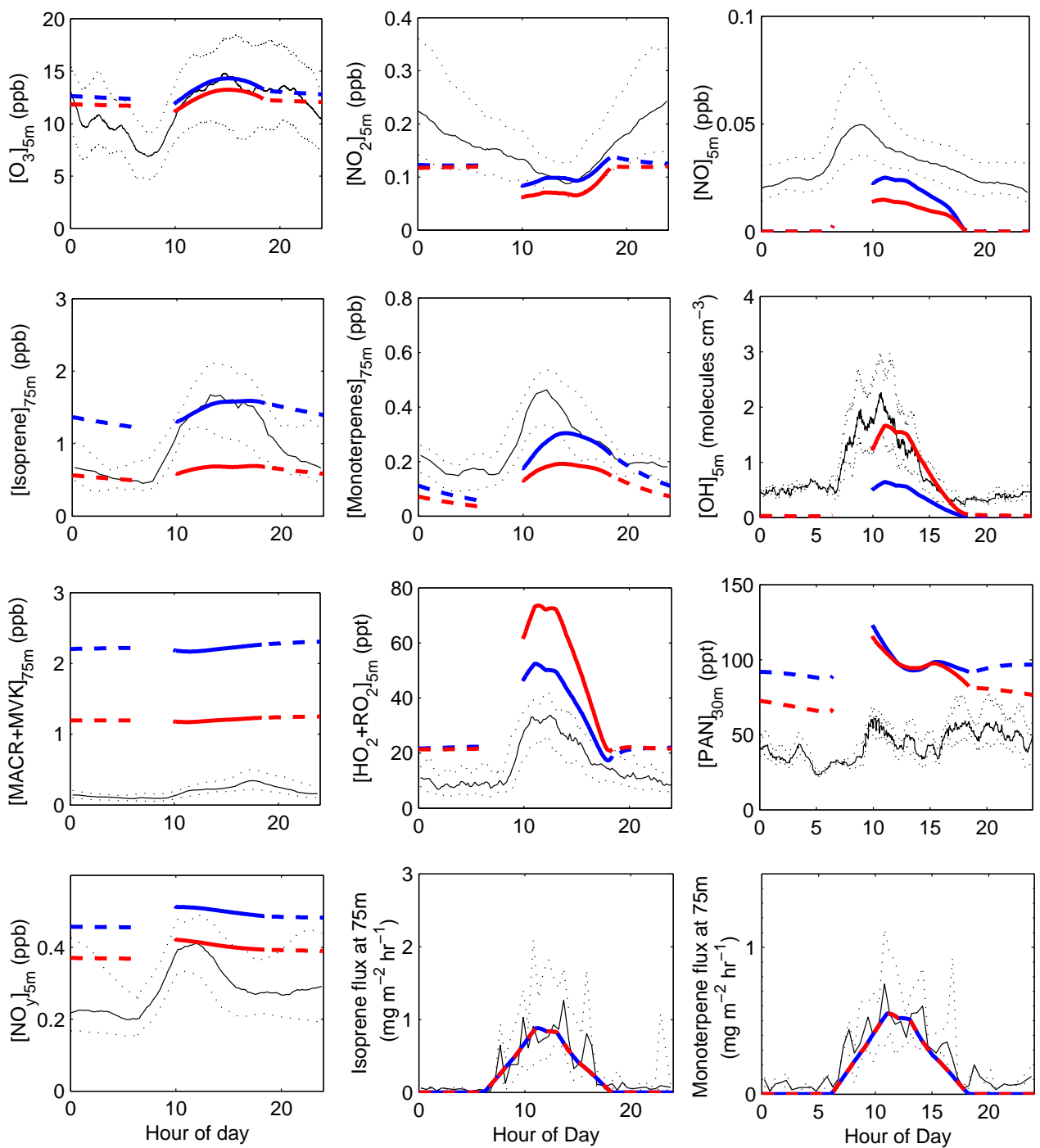

Fig. 3. Comparison of model output with (red line) and without (blue line) $\mathrm{OH}$ recycling of $m=3.0$ against the OP3-1 average measurement at Bukit Atur (black line). Upper and lower quartiles for the measurements are marked by grey dots. Emissions are the same for both scenarios.

resulted in only a $4 \%$ increase in the peak $[\mathrm{OH}]$, with a similarly small decrease in isoprene and monoterpene concentrations. Hence it may be concluded that recycling of $\mathrm{OH}$ via the reaction of carbonyl containing peroxy radicals is only able to produce a very small fraction of the missing $\mathrm{OH}$.

In order to test the hypothesis that unknown $\mathrm{OH}$ recycling within the isoprene oxidation scheme could improve the model fit, a tetra-variate sensitivity study was carried out, varying $\mathrm{OH}$ recycling, isoprene, monoterpene and $\mathrm{NO}$ emissions. Rather than assume a method for $\mathrm{OH}$ recycling, the generic reaction,

ISOPRENE $+\mathrm{OH} \rightarrow \mathrm{ISOPROO}+\mathrm{mOH}$ was used. The cost function unambiguously returned a minimum at $m=0.0$, showing that "artificial" $\mathrm{OH}$ recycling did not improve the model fit to the measurements.

To try and understand this lack of improvement, a run was carried out with $m=3.0$, which was sufficient to give good agreement between measured an modelled $[\mathrm{OH}]$, and utilising the emissions derived in Sect. 4. Figure 3 compares the results of this run with those shown in Fig. 2 and the observations. Once again the improved $\mathrm{OH}$ fit is at the cost of the isoprene and monoterpene profiles, whose concentrations are heavily reduced. Increasing the isoprene and monoterpene emission can bring these profiles back into line with the best fit previously achieved. However, this requires isoprene and monoterpene emissions to exceed the measured values. 


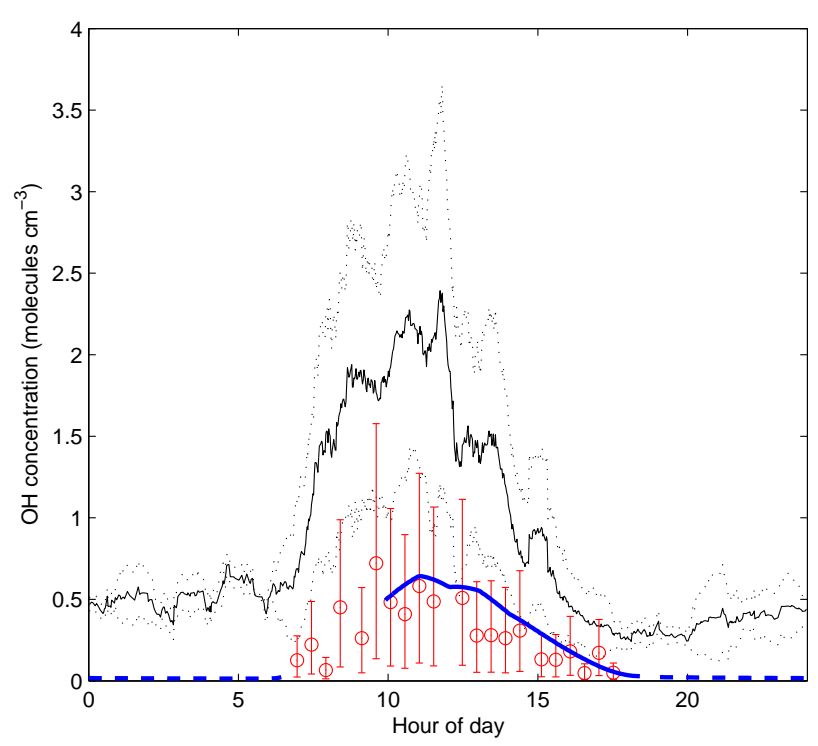

Fig. 4. Comparison of model output for $\mathrm{OH}$, for a run with the best fit emissions generated in Sect. 4 and no $\mathrm{OH}$ recycling (blue line), the OP3-1 median measurements (black line, upper and lower quartiles marked by grey dots) and the OP3-1 median $[\mathrm{OH}]$ as computed from isoprene fluxes and concentrations following Karl et al. (2007) (red dots, propagated error shown by bars).

Furthermore, this reduces the $\mathrm{OH}$ concentration almost back to the levels of no recycling, whilst the $\mathrm{HO}_{2}+\mathrm{RO}_{2}$ levels increase still further. A similar test is also carried out by constraining the model to measured $[\mathrm{OH}]$. This reduces the peak isoprene mixing ratio to $0.6 \mathrm{ppbv}$.

A recent theoretical paper by Peeters et al. (2009) postulates an alternative mechanism which may result in significant $\mathrm{OH}$ recycling via the reactions of the ISOPROO channel. The details of the Peeters et al. (2009) scheme have not been implemented here, but for the purposes of this study, it is expected to behave similarly to the simpler schemes described above. Using measurements of oxidised VOC made over the Amazon, Karl et al. (2009a) also suggest that the overall $\mathrm{HO}_{\mathrm{x}}$ recycled via this mechanism can only be $33 \%$ of that suggested by Peeters et al. (2009), in order to remain consistent with their measurements. Interestingly in regimes of intermediate NO mixing ratios, in the $100 \mathrm{~s}$ of pptv, it appears the Lelieveld et al. (2008) scheme may prove unable to produce significant amounts of $\mathrm{OH}$ (Hofzumahaus et al., 2009), whereas Peeters et al. (2009) expect their mechanism to be important up to NO mixing ratios approaching $1 \mathrm{ppbv}$.

Hofzumahaus et al. (2009) hypothesise a rather different method of $\mathrm{OH}$ recycling due to increased cycling of peroxy radicals into $\mathrm{OH}$, via an unknown compound with a similar reduction capacity to $\mathrm{NO}$; a potentially convenient solution here, given the model overestimation of $\left[\mathrm{HO}_{2}+\mathrm{RO}_{2}\right]$. This was also tested in the model by adding a compound with the same concentration and reaction rate with peroxy radicals as NO. The result was a $>100 \%$ increase in $\mathrm{OH}$ concentration for a $10 \%$ decrease in peroxy radical concentration. However the problem of modelled isoprene and $\mathrm{OH}$ concentrations not matching the measurements simultaneously is still observed. Hence for the purposes of this study this simply represents another possible method for $\mathrm{OH}$ recycling.

\subsection{Mass balance analysis}

$\mathrm{OH}$ concentrations may be calculated indirectly from the isoprene flux and concentrations after Karl et al. (2007) using,

$F_{\mathrm{s}}-F_{\mathrm{e}}=\left(k_{\mathrm{OH}} \times[\mathrm{OH}]+k_{\mathrm{O}_{3}} \times\left[\mathrm{O}_{3}\right]\right) \times C_{\text {mean }} \times z_{\text {mix }}$

where $F_{\mathrm{s}}$ is the surface flux of isoprene and $F_{\mathrm{e}}$ is the entrainment flux of isoprene from the top of the PBL into the free troposphere, $C_{\text {mean }}$ is the mean concentration of isoprene, $z_{\text {mix }}$ is the height of the PBL, and $k_{\mathrm{OH}}$ and $k_{\mathrm{O}_{3}}$ are the rate constants for the reaction with isoprene of $\mathrm{OH}$ and $\mathrm{O}_{3}$ respectively. Concentrations were only derived for the daytime due to the lack of mixing at night. The resultant $[\mathrm{OH}]$ is compared to measurements and the optimum model output (without $\mathrm{OH}$ recycling) in Fig. 4. This suggests an $\mathrm{OH}$ concentration in line with that provided by the model, suggesting that the main features of the modelled relationship between isoprene and $\mathrm{OH}$ can be represented by Eq. (3), and hence allowing a more simplified analysis of the isoprene and $\mathrm{OH}$ problem.

Measured values are available for the isoprene and $\mathrm{O}_{3}$ concentrations and the isoprene flux. Due to low concentrations and slow kinetics, the isoprene $+\mathrm{O}_{3}$ reaction is relatively unimportant. In order to increase $[\mathrm{OH}]$ in line with measurements we can reduce the net isoprene flux into the PBL by venting out of the top of the box. However this also results in a reduction in isoprene concentration, below the bounds of the measurements. Another possibility is the mixing height $\left(z_{\mathrm{mix}}\right)$. Following Eq. (3), a decrease in the mixing height would negate the need for a decrease in the isoprene concentration with a decreased flux. However, $z_{\text {mix }}$ may be estimated quite accurately from the lidar measurements. Furthermore halving the daytime $z_{\text {mix }}$ from $800 \mathrm{~m}$ to $400 \mathrm{~m}$, whilst appropriately reducing the emitted fluxes, realises only a $4 \%[\mathrm{OH}]$ increase.

The only remaining possibility is the rate of reaction. The utilised rate constants for the reactions of isoprene with $\mathrm{OH}$ and $\mathrm{O}_{3}\left(1.0 \pm 0.2 \times 10^{-10}\right.$ and $1.27 \pm 0.25 \times$ $10^{-17} \mathrm{~cm}^{3}$ molecule $\mathrm{s}^{-1} \mathrm{~s}^{-1}$ at $298 \mathrm{~K}$ respectively) are the result of numerous studies (IUPAC, 2009). Assuming a well mixed atmosphere, such well defined rates give very little room for manoeuvre, unless an outside process can influence the rate of reaction.

\subsection{BVOC segregation}

Following the work of Krol et al. (2000), Butler et al. (2008) argue that the segregation of isoprene into distinct plumes 
may result in a depletion in $\mathrm{OH}$ within those plumes. This would invalidate the well-mixed assumption of box models and lead to a lower effective rate constant. Butler et al. (2008) suggest utilising a 50\% reduction in rate constant, which, when combined with $\mathrm{OH}$ recycling, improves their isoprene and $\mathrm{OH}$ fits.

The importance of segregation can be assessed using the Damköhler number (Da) following Krol et al. (2000),

$\mathrm{Da}=\frac{\tau_{\text {mix }}}{\tau_{\text {chem }}}$

where $\tau_{\text {chem }}$ is the chemical lifetime and $\tau_{\text {mix }}$ is the mixing timescale. If $\mathrm{Da} \approx 1$ then segregation effects are likely to be most prominent. Using average midday $[\mathrm{OH}]$ during OP3-1, yields an isoprene lifetime $\left(\tau_{\text {chem }}\right)$ of $\sim 80 \mathrm{~min}$. $\tau_{\text {mix }}$ can be approximated by the convective velocity timescale,

$t_{*}=\frac{z_{i}}{w_{*}}$

where,

$w_{*}=\left[\frac{g \times z_{i}}{T_{\mathrm{v}}} F_{\mathrm{H}}\right]^{\frac{1}{3}}$

where $z_{i}$ is the height of the boundary layer, $g$ is acceleration due to gravity, $T_{\mathrm{v}}$ is the virtual temperature and $F_{\mathrm{H}}$ is the kinematic heat flux. Using average values yields $w_{*}=1.4 \mathrm{~m} \mathrm{~s}^{-1}$ at midday, giving $t_{*}=9 \mathrm{~min}$. In this case $\mathrm{Da}=0.1$, suggesting that the role of segregation at Bukit Atur may be limited. However the range of $\mathrm{OH}$ measurements is large, with peak concentrations $>6 \times 10^{6}$ molecules $\mathrm{cm}^{-3}$ recorded on some days. An $\mathrm{OH}$ concentration of this magnitude would result in an isoprene lifetime of $\sim 28 \mathrm{~min}$, and hence a Damköhler number much closer to unity. In comparison, Butler et al. (2008) suggest an isoprene lifetime of $<30$ min over the Guyanas, which is comparable to the estimated convective mixing timescale during their campaign of 8-16 min. In order to definitively prove the segregation hypothesis, high-frequency, co-located measurements of VOCs and $\mathrm{OH}$ are required. These are not available from the OP3 or other campaigns.

In order to ascertain whether reducing the rate constant could improve the model fit, the sensitivity study outlined in Sect. 4 was carried out with a 50\% reduction in the effective rate constant of $\mathrm{OH}+$ isoprene. As any physical process affecting the $\mathrm{OH}+\mathrm{isoprene}$ rate would also likely affect the $\mathrm{OH}+$ monoterpene rate, reduction factors are also applied to these reactions. Applying the cost function defined in Eq. (2) to this run generated a minima of $C_{\text {total }}=1.83$ at a $24 \mathrm{~h}$ average monoterpene emission of $0.15 \mathrm{mg} \mathrm{m}^{-2} \mathrm{~h}^{-1}$, an isoprene emission of $0.18 \mathrm{mg} \mathrm{m}^{-2} \mathrm{~h}^{-1}$ and NO emission of $0.005 \mathrm{mg} \mathrm{N} \mathrm{m}^{-2} \mathrm{~h}^{-1}$.

Model output using these settings is shown in red in Fig. 5. The green line shows a model run with the same emission rates, but without the change in effective rate constant, so as to show the effect of the rate constant reduction more clearly.
$\mathrm{OH}$ concentrations are $\sim 50 \%$ higher, whilst the fit to isoprene is maintained. A substantial decrease in modelled isoprene emission is required to generate this fit. A possible justification for this could be venting out of the boundary layer, as the previous reason for not lowering isoprene emission, its concentration falling too low, is no longer relevant. However no data regarding isoprene flux out of the boundary layer is available to test this theory.

$\mathrm{O}_{3}$ and $\mathrm{NO}_{\mathrm{x}}$ concentrations are largely unaffected by this model scenario. The reduced quantity of oxidised VOC is evident in the modelled MACR/MVK concentrations which are reduced by $33 \%$ at midday, and in the $\mathrm{HO}_{2}+\mathrm{RO}_{2}$ and PAN concentrations, both of which are closer to the measurements. Some care however, must be taken in using the modelled MACR/MVK concentrations as support for the rate constant reduction due to the poorly understood loss processes for these compounds. Furthermore, it is possible that any physical process which impacts upon the rate of the $\mathrm{OH}+\mathrm{isoprene}$ reaction may also affect the MACR/MVK+OH reaction.

At this point it is worth considering that, whilst $\mathrm{OH}$ recycling alone was shown not to be able to reconcile $\mathrm{OH}$ and isoprene concentrations in Sect. 6.1, in conjunction with a reduced rate of reaction, it might be able to consume some of the missing isoprene flux, that would otherwise have to be vented out of the boundary layer. If the standard reaction rate between isoprene/monoterpenes and $\mathrm{OH}$ is indeed too high, the extra isoprene loss this causes would have masked the need for some $\mathrm{OH}$ recycling in Sect. 6.1. This will be addressed further in Sect. 6.4.

\subsection{Further discussion}

In the analysis presented herein, isoprene concentrations are relatively low compared to other studies over a tropical rainforest. For example, Karl et al. (2007) report an average noon isoprene flux of $7.8 \mathrm{mg} \mathrm{m}^{-2} \mathrm{~h}^{-1}$, around seven times larger than that during OP3-1, leading to a peak measured isoprene mixing ratio of $\sim 7 \mathrm{ppbv}$. Modelled isoprene concentration for OP3-1 is approaching steady state after 8 days and is very close to the observations. However, entering the Karl et al. (2007) flux into the CiTTyCAT model causes mixing ratios of isoprene to accumulate to highly unrealistic levels of over $100 \mathrm{ppbv}$, clearly indicating an underestimation of the isoprene sinks. Note that this is not an attempt to simulate the Karl et al. (2007) regime, as differences in temperature, boundary layer dynamics, etc are not considered, and to do so would be beyond the scope of this paper. However, the extent of the isoprene accumulation can be explained by considering the relative contributions to $\mathrm{OH}$ production. Making the assumptions that every reaction of isoprene and $\mathrm{OH}$ regenerates one $\mathrm{OH}$ radical and other $\mathrm{OH}$ production is dominated by Reaction (R1),

$\mathrm{O}\left({ }^{1} \mathrm{D}\right)+\mathrm{H}_{2} \mathrm{O} \rightarrow 2 \mathrm{OH}$ 

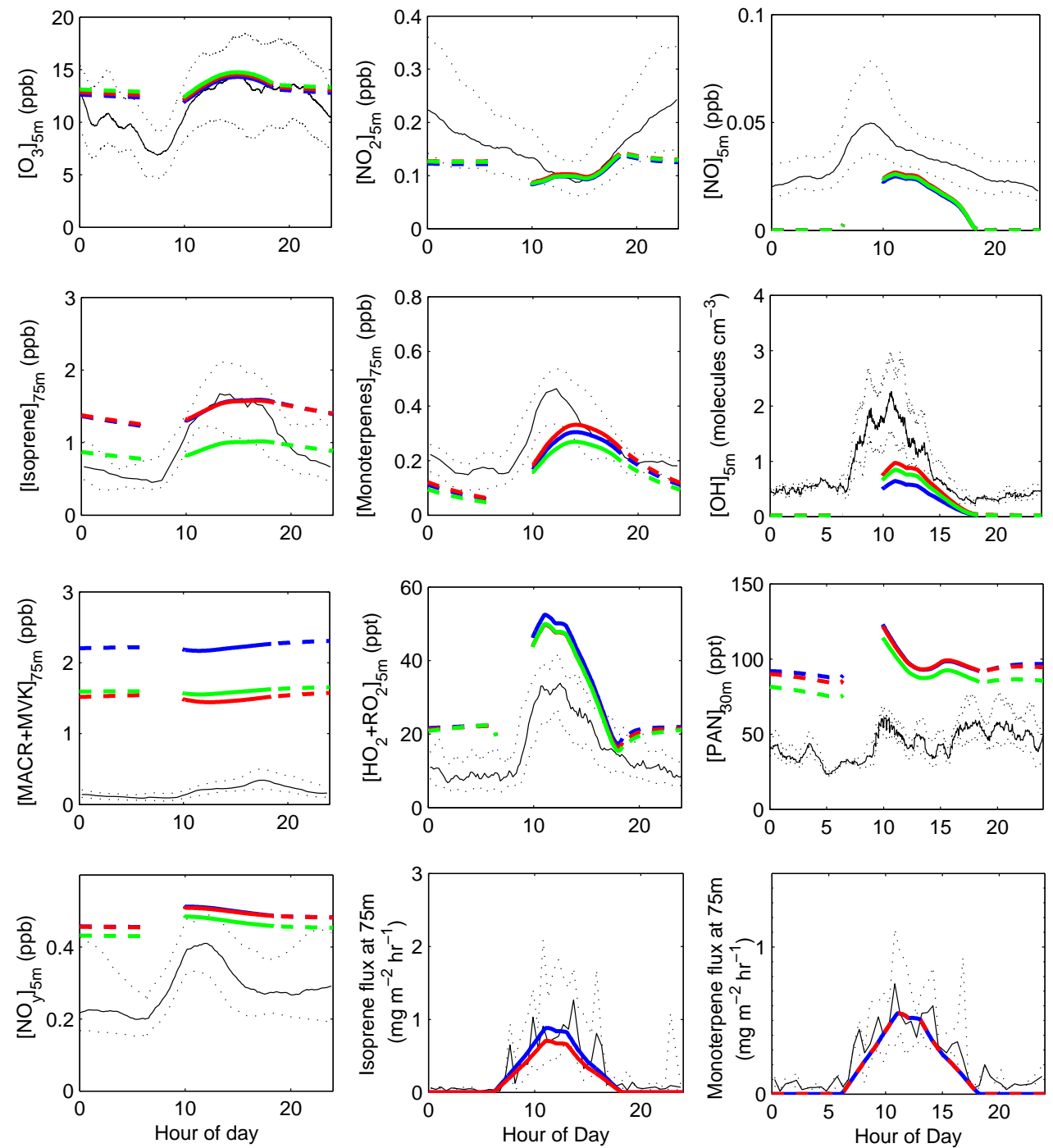

Fig. 5. Comparison of model output with the OP3-1 average measurements at Bukit Atur (black line). The blue line is the run shown in Fig. 2. The red line is a run with the isoprene+ $\mathrm{OH}$ rate constant reduced by $50 \%$ and the emissions adjusted as per the best fit. The green line shows the effect of the emissions change alone.

it is possible to estimate the potential contribution of $\mathrm{OH}$ recycling to the overall $\mathrm{OH}$ production using,

$$
\begin{aligned}
& \frac{\mathrm{OH}_{\text {prod }}}{d t}=2\left(k_{1}\left[\mathrm{O}^{1} \mathrm{D}\right]\left[\mathrm{H}_{2} \mathrm{O}\right]\right)+k_{2}\left[\mathrm{HO}_{2}\right][\mathrm{NO}] \\
& +k_{3}[\mathrm{Iso}][\mathrm{OH}]
\end{aligned}
$$

where $k_{1}, k_{2}$ and $k_{3}$ are the rate constants for the respective reactions. Entering average midday measured concentrations (except for $\mathrm{O}\left({ }^{1} \mathrm{D}\right)$ and $\mathrm{HO}_{2}$ where modelled concentrations are used in the absence of measurements), shows that $4.1 \times 10^{6}$ molecules $\mathrm{OH} \mathrm{cm}^{-3} \mathrm{~s}^{-1}$ are contributed by Reactions (R4) and (R1), whilst $7.4 \times 10^{6}$ molecules $\mathrm{OH} \mathrm{cm}^{-3} \mathrm{~s}^{-1}$ are contributed by isoprene+OH. Hence $\mathrm{OH}$ recycling via isoprene would contribute $64 \%$ of $\mathrm{OH}_{\text {prod }}$. However, with an isoprene mixing ratio of $7 \mathrm{ppbv}$, and all other concentra- tions remaining equal, $\mathrm{OH}$ recycling via isoprene would contribute $32.2 \times 10^{6}$ molecules $\mathrm{OH} \mathrm{cm} \mathrm{cm}^{-3} \mathrm{~s}^{-1}$ or $89 \%$ of $\mathrm{OH}_{\text {prod. }}$. Of course these percentages will vary depending on the yield of $\mathrm{OH}$ assumed.

Hence $\mathrm{OH}$ recycling has the potential to dominate $\mathrm{OH}_{\text {prod }}$ in high isoprene environments, such as observed by Karl et al. (2007), where neglecting to consider it would be to potentially ignore the principal source of $\mathrm{OH}$ production. However, considering that a reduced effective rate constant for isoprene+ $\mathrm{OH}$ may reduce the contribution of $\mathrm{OH}$ recycling by half, its effect in the regime measured during OP31 may be greatly reduced. Overall, it is clear from the results presented above, that whilst there may be an important role for unknown $\mathrm{OH}$ recycling in moderating modelled isoprene to reasonable levels in the most isoprene-rich tropical 

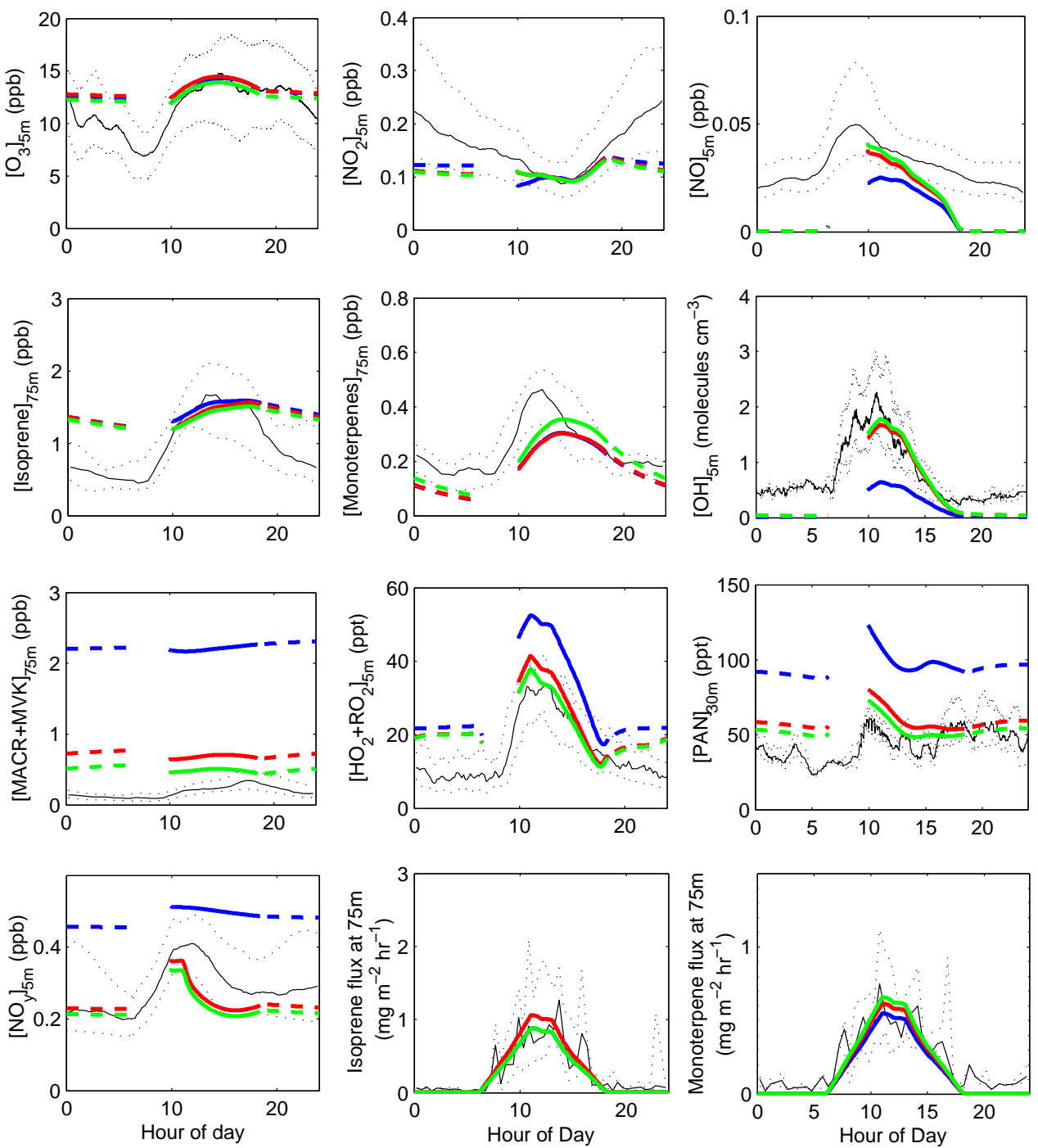

Fig. 6. Comparison of model output with the OP3-1 average measurements at Bukit Atur (black line). The blue line is the run shown in Fig. 2. The red line is shows $\mathrm{S} 1$ and the green line shows S2, as described in Sect. 6.4.

environments, it is not able to fully explain the modelled underestimation of $[\mathrm{OH}]$ in all cases.

Given that several factors presented herein have been able to affect the $\mathrm{VOC}+\mathrm{OH}$ chemistry, a final sensitivity study of 10000 runs is carried out, varying the effective rate of isoprene/monoterpenes $+\mathrm{OH}, V_{\mathrm{d}(\mathrm{MACR}+\mathrm{MVK})}, \mathrm{OH}$ recycling via Reaction (R3) and emissions of isoprene, monoterpenes and NO. Wet deposition is also enabled. Two potential best fits are found in the parameter space. The reason for this behaviour being that both $\mathrm{OH}$ recycling in the isoprene oxidation scheme and greater deposition of MACR and MVK result in the required increase in $\mathrm{OH}$. Therefore more information is required to determine the exact position of this balance.
The fit returned at $C_{\text {total }}=1.11$, referred to below as $\mathrm{S} 1$, gives an effective rate for isoprene/monoterpenes+OH $50 \%$ of the IUPAC value, $V_{\mathrm{d}(\mathrm{MACR}+\mathrm{MVK})}=1.5 \mathrm{~cm} \mathrm{~s}^{-1}$ and $m=0.25$. Emissions of isoprene and monoterpenes were 0.28 and $0.17 \mathrm{mg} \mathrm{m}^{-2} \mathrm{~h}^{-1}$ respectively, and those for NO, $0.007 \mathrm{mg} \mathrm{N} \mathrm{m}^{-2} \mathrm{~h}^{-1}$. The fit returned at $C_{\text {total }}=$ 0.99 , referred to below as $\mathrm{S} 2$, has the same rate constant reduction of $50 \%$ and the same NO emssion, but $V_{\mathrm{d}(\mathrm{MACR}+\mathrm{MVK})}=2.5 \mathrm{~cm} \mathrm{~s}^{-1}$ and $m=0.0$. Emissions of isoprene and monoterpenes were 0.26 and $0.18 \mathrm{mg} \mathrm{m}^{-2} \mathrm{~h}^{-1}$ respectively. Analysis of the output concentrations shown in Fig. 6 demonstrates that both give a good fit within the measurement uncertainty.

There is a $71 \%(72 \%)$ reduction in the contribution of $\mathrm{OH}$ to $C_{\text {total }}$ for $\mathrm{S} 1$ (S2), giving an $\mathrm{MBE}$ for $\mathrm{OH}$ of $-9 \%(-5 \%)$, well within measurement uncertainty, whilst maintaining 
isoprene and monoterpene fits. In Sect. 2 it was demonstrated that the 5-m OH measurements may underestimate boundary layer $\mathrm{OH}$ by up to $30 \%$. The optimised model fit would still lie in the uncertainty bounds of the $\mathrm{OH}$ measurements for both $\mathrm{S} 1$ and $\mathrm{S} 2$ even if such a gradient in $\mathrm{OH}$ exists. Notably secondary species such as $\mathrm{HO}_{2}+\mathrm{RO}_{2}, \mathrm{PAN}$ and $\mathrm{NO}_{\mathrm{y}}$ also show improved fits to the measurements, further demonstrating the importance of the physical processes considered to accurate simulations of the chemistry.

Although this study is unable to precisely define the relative contributions of MACR/MVK deposition and $\mathrm{OH}$ recycling, these results offer an improved explanation in many respects. Regardless of whether S1 or S2 is chosen, the measured emissions of isoprene and monoterpenes are fully accounted for, whilst the rate constant reduction of $50 \%$ required to generate the improved $\mathrm{OH}$ fit is the same as that suggested by Butler et al. (2008). Although such a reduction in rate is substantial, Krol et al. (2000) find rate reductions between a reactive hydrocarbon $(\mathrm{RH})$ and $\mathrm{OH}$ up to $29.4 \%$ using a Large Eddy Simulation model with heterogeneous NO and VOC emissions. As the rate they utilise for the reaction of $\mathrm{OH}+\mathrm{RH}$ is approximately one quarter of that between isoprene and $\mathrm{OH}$ at $298 \mathrm{~K}$ (IUPAC, 2009), it is reasonable that even stronger segregation may exist for the latter reaction. Vinuesa and Vilà-Guerau de Arellano (2005) suggest a reduction of $40.5 \%$ for a reaction of $\mathrm{OH}+\mathrm{RH}$ with a similar rate to isoprene+OH. When the stated $20 \%$ error in the isoprene+OH rate constant (IUPAC, 2009) is taken into account, the reductions here do not appear unreasonable. It is important to note that whilst the agreement with Butler et al. (2008) is good, this by no means infers that $50 \%$ rate constant reductions for isoprene/monoterpenes $+\mathrm{OH}$ should be applied in every situation. A different forest landscape, for instance one with a less varied distribution of NO or VOC emitting species or different turbulent mixing characteristics, might be expected to experience a different intensity of segregation.

An $\mathrm{OH}$ recycling fit of between $m=0.0$ and $m=0.25$ is small, demonstrating the magnitude of recycling required in this scenario is much less than has been suggested in other studies. However, it is close to the yield of $m=0.22$, calculated by Karl et al. (2009a) when they adjust the Peeters et al. (2009) mechanism to fit their field observations. Detailed analysis as to the source of such $\mathrm{OH}$ recycling is left to other papers in this issue. As for the rate constant reductions, these results are representative of the region studied and it is not necessarily the case that an unaccounted for yield of $\mathrm{OH}$ recycling should be the same for all regions. For instance the Hofzumahaus et al. (2009) recycling hypothesis mentioned earlier is based upon an as yet unidentified reduction agent similar to NO. The global or regional distribution of such an agent might vary considerably. In the case of an omission in the isoprene oxidation scheme (e.g. Lelieveld et al., 2008; Peeters et al., 2009), under the subtly different temperature and chemical conditions encountered in different regions, the yield along such a pathway might vary considerably.

\section{$7 \quad$ Summary and conclusions}

To our knowledge, this is the first modelling study of the chemistry occurring in the tropical rainforest PBL to utilise such a wide suite of ground-based measurements, including both $[\mathrm{OH}]$ measurements and VOC fluxes, to inform the modelling. It is also the first detailed model:measurement comparison over the relatively unstudied South-East Asian rainforest. The ability of the CiTTyCAT model to represent the broad features of atmospheric composition above a tropical rainforest has been demonstrated. In particular the model appears to perform robustly with respect to $\mathrm{NO}_{\mathrm{x}}$ and $\mathrm{O}_{3}$ chemistry. The potential to generate net fluxes of compounds into the PBL, utilising ambient concentration measurements has also been shown, and the technique may be applied to estimate fluxes where measurements are not available, or PBL venting where they are, assuming a sufficient knowledge of the local chemistry and mixing. However modelling chemistry above the South-East Asian rainforest is shown to suffer the same problems with reconciling BVOC and $\mathrm{OH}$ concentrations highlighted in other tropical modelling studies.

It has been shown that both dry and wet deposition of intermediate VOC oxidation products can have a very significant influence on both their concentrations and the oxidation capacity of the boundary layer. It is critical that further investigation into deposition processes over tropical forests is carried out, in order to reduce the uncertainties in these regions. The importance of considering micrometerological mixing processes when modelling compounds of intermediate atmospheric lifetime such as isoprene has also been highlighted.

In the light of the work presented here, it appears that inadequacies apparent in box and global model studies of tropical VOC chemistry may be more strongly influenced by representation of detailed physical and micrometeorological effects than by errors in the chemical scheme. Further measurement work is required to fully understand the nature of these processes, so that they may be accounted for effectively in future studies.

Acknowledgements. This work was funded by the Natural Environment Research Council (award NE/D0 02117/1). The authors would like to thank Brian Davison for organising the campaign logistics and Glen Reynolds and the Royal Society for the support they provided prior to and during the campaign. They also thank, T. Karl, L. Ganzeveld, J. Vila, R. Cohen, E. Browne, N. Carslaw and an annoymous reviewer for their comments on the manuscript and F. Davies and G. Pearson for their advice regarding the LIDAR measurements. They would also like to acknowledge all the members of the OP3 team who provided advice and discussion during this work. The cooperation of the Malaysian Meteorological Service in providing the Bukit Atur site is very gratefully appreciated. This is paper number 503 of the Royal Society's South East Asian Rainforest Research Programme.

Edited by: W. T. Sturges 


\section{References}

Andreae, M. and Merlet, P.: Emissions of trace gases and aerosols from biomass burning, Global Biogeochem. Cy., 15, 955-966, 2001.

Atkinson, R. and Arey, J.: Gas-phase tropospheric chemistry of biogenic volatile organic compounds: a review, Atmos. Environ., 37, S197-S219, 2003.

Butler, T. M., Taraborrelli, D., Brühl, C., Fischer, H., Harder, H., Martinez, M., Williams, J., Lawrence, M. G., and Lelieveld, J.: Improved simulation of isoprene oxidation chemistry with the ECHAM5/MESSy chemistry-climate model: lessons from the GABRIEL airborne field campaign, Atmos. Chem. Phys., 8, 4529-4546, 2008,

http://www.atmos-chem-phys.net/8/4529/2008/.

Carslaw, N., Creasey, D. J., Harrison, D., Heard, D. E., Hunter, M. C., Jacobs, P. J., Jenkin, M. E., Lee, J. D., Lewis, A. C., Pilling, M. J., Saunders, S. M., and Seakins, P. W.: $\mathrm{OH}$ and $\mathrm{HO}_{2}$ radical chemistry in a forested region of north-western Greece, Atmos. Environ., 35, 4725-4737, 2001.

Carter, W. P. L. and Atkinson, R.: Development and evaluation of a detailed meachanism for the atmospheric reactions of isoprene and $\mathrm{NO}_{\mathrm{x}}$, Int. J. Chem. Kinet., 28, 497-530, 1996.

Chappell, N., Bidin, K., and Tych, W.: Modelling rainfall and canopy controls on net-precipitation beneath selectively-logged forest, Plant Ecol., 153, 215-229, 2001

Chen, X., Hulbert, D., and Shepson, P. B.: Measurement of the origanic nitrate yield from $\mathrm{OH}$ reaction with isoprene, J. Geophys. Res., 95, 22319-22341, 1998.

Cleveland, C. C. and Yavitt, J. B.: Consumption of atmospheric isopene in soil, Geophys. Res. Lett., 24, 2379-2382, 1997.

Cook, P., Savage, N., Turquety, S., Carver, G., O'Connor, F., Heckel, A., Stewart, D., Whalley, L., Parker, A., Schlager, H., Avery, H. S. M., Sachse, G., Brune, W., Richter, A., Burrows, J., Purvis, R., Lewis, A., Reeves, C., Monks, P., Levine, J., and Pyle., J.: Forest fire plumes over the North Atlantic: p-TOMCAT model simulations with aircraft and satellite measurements from the ITOP/ICARTT campaign, J. Geophys. Res., 112, D10S43, doi:10.1029/2006JD007563, 2007.

Dillon, T. J. and Crowley, J. N.: Direct detection of $\mathrm{OH}$ formation in the reactions of $\mathrm{HO}_{2}$ with $\mathrm{CH}_{3} \mathrm{C}(\mathrm{O}) \mathrm{O}_{2}$ and other substituted peroxy radicals, Atmos. Chem. Phys., 8, 4877-4889, 2008, http://www.atmos-chem-phys.net/8/4877/2008/.

Donovan, R., Hope, E., Owen, S., Mackenzie, A., and Hewitt, C.: Development and Application of an Urban Tree Air Quality Score for Photochemical Pollution Episodes Using the Birmingham, United Kingdom, Area as a Case Study, Environ. Sci. Technol., 39, 6730-6738, 2005.

Edwards, P., Whalley, L. K., Heard, D. E., et al.: OH reactivity measurements in a South-East Asian tropical Rainforest, Atmos. Chem. Phys. Discuss., in preparation, 2010.

Eerdekens, G., Yassaa, N., Sinha, V., Aalto, P. P., Aufmhoff, H., Arnold, F., Fiedler, V., Kulmala, M., and Williams, J.: VOC measurements within a boreal forest during spring 2005: on the occurrence of elevated monoterpene concentrations during night time intense particle concentration events, Atmos. Chem. Phys., 9, 8331-8350, 2009,

http://www.atmos-chem-phys.net/9/8331/2009/.

Emmerson, K. M., MacKenzie, A. R., Owen, S. M., Evans, M. J., and Shallcross, D. E.: A Lagrangian model with simple primary and secondary aerosol scheme 1: comparison with UK $\mathrm{PM}_{10}$ data, Atmos. Chem. Phys., 4, 2161-2170, 2004,

http://www.atmos-chem-phys.net/4/2161/2004/.

Emmerson, K. M., Carslaw, N., Carpenter, L. J., Heard, D. E., Lee, J. D., and Pilling, M. J.: Urban Atmospheric Chemistry during the PUMA Campaign, 1: Comparison of Modelled $\mathrm{OH}$ and $\mathrm{HO}_{2}$ Concentrations with Measurements, J. Atmos. Chem., 52(2), 143-164, 2005.

Emmerson, K. M., Carslaw, N., Carslaw, D. C., Lee, J. D., McFiggans, G., Bloss, W. J., Gravestock, T., Heard, D. E., Hopkins, J., Ingham, T., Pilling, M. J., Smith, S. C., Jacob, M., and Monks, P. S.: Free radical modelling studies during the UK TORCH Campaign in Summer 2003, Atmos. Chem. Phys., 7, 167-181, 2007, http://www.atmos-chem-phys.net/7/167/2007/.

Evans, M., Shallcross, D., Law, K., Wild, J., Simmonds, P., Spain, T., Berrisford, P., Methven, J., Lewis, A., McQuaid, J., Pilling, M., Bandy, B., Penkett, S., and Pyle, J.: Evaluation of a Lagrangian box model using field measurements from EASE (Eastern Atlantic Summer Experiment) 1996, Atmos. Environ., 34, 3843-3863, 2000.

Fisch, G., Tota, J., Machado, L. A. T., Silva Dias, M. A. F., da Lyra, R. F., Nobre, C. A., Dolman, A. J., and Gash, J. H. C.: The convective boundary layer over pasture and forest in Amazonia, Theor. Appl. Climatol., 78(1-3), 47-59, doi:10.1007/s00704004-0043-x, 2004.

Farmer, D. K. and Cohen, R. C.: Observations of $\mathrm{HNO}_{3}, \Sigma \mathrm{AN}$, $\Sigma \mathrm{PN}$ and $\mathrm{NO}_{2}$ fluxes: evidence for rapid $\mathrm{HOx}$ chemistry within a pine forest canopy, Atmos. Chem. Phys., 8, 3899-3917, 2008, http://www.atmos-chem-phys.net/8/3899/2008/.

Fuentes, J., Lerdau, M., Atkinson, R., Baldocchi, D., Bottenheim, J., Ciccioli, P., Lamb, B., Geron, C., Gu, L., Guenther, A., Sharkey, T., and Stockwell, W.: Biogenic hydrocarbons in the atmospheric boundary layer: A review, B. Am. Meteor. Soc., 81, 1537-1575, 2000.

Fuentes, J. D., Wang, D., Bowling, D. R., Potosnak, M., Monson, R. K., Goliff, W. S., and Stockwell, W. R.: Biogenic Hydrocarbon Chemistry within and Above a Mixed Deciduous Forest, J. Atmos. Chem., 56, 165-185, 2007.

Ganzeveld, L. N., Lelieveld, J. Dentener, F. J., Krol, M. C., Bouwman, A. J., and Roelofs, G.-J.: Global soil-biogenic $\mathrm{NO}_{\mathrm{x}}$ emissions and the role of canopy processes, J. Geophys. Res., 107(D16), 4298, doi:10.1029/2001JD001289, 2002.

Ganzeveld, L., Eerdekens, G., Feig, G., Fischer, H., Harder, H., Königstedt, R., Kubistin, D., Martinez, M., Meixner, F. X., Scheeren, H. A., Sinha, V., Taraborrelli, D., Williams, J., VilàGuerau de Arellano, J., and Lelieveld, J.: Surface and boundary layer exchanges of volatile organic compounds, nitrogen oxides and ozone during the GABRIEL campaign, Atmos. Chem. Phys., 8, 6223-6243, 2008, http://www.atmos-chem-phys.net/8/6223/2008/.

George, L. A., Hard, T. M., and O'Brien, R. J.: Measurement of free radicals $\mathrm{OH}$ and $\mathrm{HO}_{2}$ in Los Angeles smog, J. Geophys. Res., 104, 11643-11655, 1999.

Geyer, A. and Stutz, J.: The vertical structure of $\mathrm{OH}-\mathrm{HO}_{2}-\mathrm{RO}_{2}$ chemistry in the nocturnal boundary layer: A one-dimensional model study, J. Geophys. Res., 109, D16301, doi:\{10.1029/ 2003JD004425\}, 2004.

Giacopelli, P., Ford, K., Espada, C. and Shepson, P. B.: Comparison of the measured and simulated isoprene nitrate distri- 
butions above a forest canopy, J. Geophys. Res., 110, D01304, doi:10.1029/2004JD005123, 2005.

Guenther, A., Hewitt, C., Erickson, D., Fall, R., Geron, C., Graedel, T., Harley, P., Klinger, L., Lerdau, M., McKay, W., Pierce, T., Scholes, B., Steinbrecher, R., Tallamraju, R., Taylor, J., and Zimmerman, P.: A global model of natural volatile organic compound emissions, J. Geophys. Res., 100, 8873-8892, 1995.

Guenther, A., Karl, T., Harley, P., Wiedinmyer, C., Palmer, P. I., and Geron, C.: Estimates of global terrestrial isoprene emissions using MEGAN (Model of Emissions of Gases and Aerosols from Nature), Atmos. Chem. Phys., 6, 3181-3210, 2006, http://www.atmos-chem-phys.net/6/3181/2006/.

Hasson, A., Tyndall, G., and Orlando, J.: A product yield study of the reaction of $\mathrm{HO}_{2}$ radicals with ethyl peroxy $\left(\mathrm{C}_{2} \mathrm{H}_{5} \mathrm{O}_{2}\right)$, acetyl peroxy $\left(\mathrm{CH}_{3} \mathrm{C}(\mathrm{O}) \mathrm{O}_{2}\right)$, and acetonyl peroxy $\left(\mathrm{CH}_{3} \mathrm{C}(\mathrm{O}) \mathrm{CH}_{2} \mathrm{O}_{2}\right)$ radicals, J. Phys. Chem. A, 108, 5979-5989, doi:\{10.1021/ jp048873t\}, 2004.

Hewitt, C. N., Lee, J. D., MacKenzie, A. R., Barkley, M. P., Carslaw, N., Carver, G. D., Chappell, N. A., Coe, H., Collier, C., Commane, R., Davies, F., Davison, B., DiCarlo, P., Di Marco, C. F., Dorsey, J. R., Edwards, P. M., Evans, M. J., Fowler, D., Furneaux, K. L., Gallagher, M., Guenther, A., Heard, D. E., Helfter, C., Hopkins, J., Ingham, T., Irwin, M., Jones, C., Karunaharan, A., Langford, B., Lewis, A. C., Lim, S. F., MacDonald, S. M., Mahajan, A. S., Malpass, S., McFiggans, G., Mills, G., Misztal, P., Moller, S., Monks, P. S., Nemitz, E., Nicolas-Perea, V., Oetjen, H., Oram, D. E., Palmer, P. I., Phillips, G. J., Pike, R., Plane, J. M. C., Pugh, T., Pyle, J. A., Reeves, C. E., Robinson, N. H., Stewart, D., Stone, D., Whalley, L. K., and Yin, X.: Overview: oxidant and particle photochemical processes above a south-east Asian tropical rainforest (the OP3 project): introduction, rationale, location characteristics and tools, Atmos. Chem. Phys., 10, 169-199, 2010,

http://www.atmos-chem-phys.net/10/169/2010/.

Hewitt, C. N., MacKenzie, A. R., Di Carlo, P., Di Marco, C. F., Dorsey, J. R., Evans, M., Fowler, D., Gallagher, M. W., Hopkins, J. R., Jones, C. E., Langford, B., Lee, J. D., Lewis, A. C., Lim, S. F., McQuaid, J., Misztal, P., Moller, S. J., Monks, P. S., Nemitz, E., Oram, D. E., Owen, S. M., Phillips, G. J., Pugh, T. A. M., Pyle, J. A., Reeves, C. E., Ryder, J., Siong, J., Skiba, U., and Stewart, D. J.: Nitrogen management is essential to prevent tropical oil palm plantations from causing ground-level ozone pollution, P. Natl. Acad. Sci. USA, 106, 18447-18451, 2009.

Hofzumahaus, A., Rohrer, F., Lu, K., Bohn, B., Brauers, T., Chang, C.-C., Fuchs, H., Holland, F., Kita, K., Kondo, Y., Li, X., Lou, S., Shao, M., Zeng, L., Wahner, A., and Zhang, Y.: Amplified Trace Gas Removal in the Troposphere, Science, 324, 1702-1704, doi: \{10.1126/science.1164566\}, 2009.

Holzinger, R., Lee, A., Paw, K. T., and Goldstein, U. A. H.: Observations of oxidation products above a forest imply biogenic emissions of very reactive compounds, Atmos. Chem. Phys., 5, 67-75, 2005,

http://www.atmos-chem-phys.net/5/67/2005/.

Horowitz, L. W., Fiore, A. M., Milly, G. P., Cohen, R. C., Perring, A., Wooldridge, P. J., Hess, P. G., Emmons, L. K., and Lamarque, J.-F.: Observational constraints on the chemistry of isoprene nitrates over the eastern United States, J. Geophys. Res., 112, doi:\{10.1029/2006JD007747\}, 2007.

Horii, C. V., Munger, J. W., Wofsy, S. C., Zahniser, M., Nelson, D., and McManus, J. B.: Atmospheric reactive nitrogen concentration and flux budgets at a northeastern US forest site, Agric. For. Meteorol., 136, 159-174, 2006.

IUPAC: Evaluated kinetic data, http://www.iupac-kinetic.ch.cam. ac.uk/, last access: 19th March 2009, 2009.

Jenkin, M.: Chemical Mechanisms forming condensable material, Tech. Rep. AEA/RAMP/2001 0010/002, AEA, 1996.

Jenkin, M. E., Hurley, M. D., and Wallington, T. J.: Investigation of the radical product channel of the $\mathrm{CH}_{3} \mathrm{C}(\mathrm{O}) \mathrm{O}_{2}+\mathrm{HO}_{2}$ reaction in the gas phase, Phys. Chem. Chem. Phys., 9, 3149-3162, doi: \{10.1039/b702757e\}, 2007.

Kanaya, Y., Cao, R., Kato, S., Miyakawa, Y., Kajii, Y., Tanimoto, H., Yokouchi, Y., Mochida, M., Kawamura, K., and Akimoto, H.: Chemistry of $\mathrm{OH}$ and $\mathrm{HO}_{2}$ radicals observed at Rishiri Island, Japan, in September 2003: Missing daytime sink of $\mathrm{HO}_{2}$ and positive nighttime correlations with monoterpenes, J. Geophys. Res., 112, D11308, doi:10.1029/2006JD007987, 2007.

Karl, T., Potosnak, M., Guenther, A., Clark, D., Walker, J., Herrick, J., and Geron, C.: Exchange processes of volatile organic compounds above a tropical rain forest: Implications for modeling tropospheric chemistry above dense vegetation, J. Geophys. Res., 109, D18306, doi:\{10.1029/2004JD004738\}, 2004.

Karl, T., Guenther, A., Yokelson, R. J., Greenberg, J., Potosnak, M., Blake, D. R., and Artaxo, P.: The tropical forest and fire emissions experiment: Emission, chemistry, and transport of biogenic volatile organic compounds in the lower atmosphere over Amazonia, J. Geophys. Res., 112, D18302, doi:\{10.1029/ 2007JD008539\}, 2007.

Karl, T., Guenther, A., Turnipseed, A., Tyndall, G., Artaxo, P., and Martin, S.: Rapid formation of isoprene photo-oxidation products observed in Amazonia, Atmos. Chem. Phys., 9, 7753-7767, 2009 ,

http://www.atmos-chem-phys.net/9/7753/2009/.

Karl, T.: Interactive comment on "Simulating atmospheric composition over a South-East Asian tropical rainforest: Performance of a chemistry box model" by T. A. M. Pugh et al., Atmos. Chem. Phys. Discuss., 9, C6470-C6473, 2009.

Kleffmann, J.: Daytime Sources of Nitrous Acid (HONO) in the Atmospheric Boundary Layer, Chem. Phys. Chem., 8, 1137-1144, 2007.

Konrad, S., Schmitz, Th., Buers, H.-J., Houben, N., Mannschreck, K., Mihelcic, D., Müsgen, P., Pätz, H.-W., Holland, F., Hofzumahaus, A., Schäfer, H.-J., Schröder, S., and Volz-Thomas, A.: Hydrocarbon measurements at Pabstthum during the BERLIOZ campaign and modelling of free radicals, J. Geophys. Res., 108, 8251, doi:10.1029/2001JD000866, 2003.

Krejci, R., Ström, J., de Reus, M., Williams, J., Fischer, H., Andreae, M. O., and Hansson, H.-C.: Spatial and temporal distribution of atmospheric aerosols in the lowermost tropospher over the Amazonian tropical rainforest, Atmos. Chem. Phys., 5, 15271543, 2005, http://www.atmos-chem-phys.net/5/1527/2005/.

Krol, M., Molemaker, M., and de Arellano, J.: Effects of turbulence and heterogeneous emissions on photochemically active species in the convective boundary layer, J. Geophys. Res., 105, 68716884, 2000.

Kubistin, D., Harder, H., Martinez, M., Rudolf, M., Sander, R., Bozem, H., Eerdekens, G., Fischer, H., Gurk, C., Klüpfel, T., Knigstedt, R., Parchatka, U., Schiller, C. L., Stickler, A., 
Taraborrelli, D., Williams, J., and Lelieveld, J.: Hydroxyl radicals in the tropical troposphere over the Suriname rainforest: comparison of measurements with the box model MECCA, Atmos. Chem. Phys. Discuss., 8, 15239-15289, 2008,

http://www.atmos-chem-phys-discuss.net/8/15239/2008/.

Kuhn, U., Rottenberger, S., Biesenthal, T., Wolf, A., Schebeske, G., Ciccioli, P., Brancaleoni, E., Frattoni, M., Tavares, T., and Kesselmeier, J.: Seasonal differences in isoprene and lightdependent monoterpene emission by Amazonian tree species, Glob. Change Biol., 10, 663-682, doi:\{10.1111/j.1529-8817. 2003.00771.x\}, 2004.

Kuhn, U., Andreae, M. O., Ammann, C., Araújo, A. C., Brancaleoni, E., Ciccioli, P., Dindorf, T., Frattoni, M., Gatti, L. V., Ganzeveld, L., Kruijt, B., Lelieveld, J., Lloyd, J., Meixner, F. X., Nobre, A. D., Pöschl, U., Spirig, C., Stefani, P., Thielmann, A., Valentini, R., and Kesselmeier, J.: Isoprene and monoterpene fluxes from Central Amazonian rainforest inferred from towerbased and airborne measurements, and implications on the atmospheric chemistry and the local carbon budget, Atmos. Chem. Phys., 7, 2855-2879, 2007,

http://www.atmos-chem-phys.net/7/2855/2007/.

Langford, B., Davison, B., Nemitz, E., and Hewitt, C. N.: Mixing ratios and eddy covariance flux measurements of volatile organic compounds from an urban canopy (Manchester, UK), Atmos. Chem. Phys., 9, 1971-1987, 2009,

http://www.atmos-chem-phys.net/9/1971/2009/.

Langford, B., Misztal, P., Nemitz, E., Davison, B., Helfter, C., Lee, J., MacKenzie, A. R., and Hewitt, C. N.: Fluxes of volatile organic compounds from a south-east Asian tropical rainforest, Atmos. Chem. Phys. Discuss., in preparation, 2010.

Lelieveld, J., Butler, T. M., Crowley, J. N., Dillon, T. J., Fischer, H., Ganzeveld, L., Harder, H., Lawrence, M. G., Martinez, M., Taraborrelli, D., and Williams, J.: Atmospheric oxidation capacity sustained by a tropical forest, Nature, 452, 737-740, doi: \{10.1038/nature06870\}, 2008.

Martin, C. L., Fitzjarrald, D., Garstang, M., Oliveira, S. P., Greco, S., and Browell, E.: Structure and growth of the mixing layer over the Amazonian rain forest, J. Geophys. Res., 93, 13611375,1988

Martinez, M., Harder, H., Kubistin, D., Rudolf, M., Bozem, H., Eerdekens, G., Fischer, H., Gurk, C., Klüpfel, T., Königstedt, R., Parchatka, U., Schiller, C. L., Stickler, A., Williams, J., and Lelieveld, J.: Hydroxyl radicals in the tropical troposphere over the Suriname rainforest: airborne measurements, Atmos. Chem. Phys. Discuss., 8, 15491-15536, 2008,

http://www.atmos-chem-phys-discuss.net/8/15491/2008/.

Misztal, P. K., Nemitz, E., Langford, B., Coyle, M., Ryder, J., DiMarco, C., Phillips, G., Oram, D., Owen, S., and Cape, J. N.: First direct ecosystem fluxes of VOCs from oil palms in SE Asia, Atmos. Chem. Phys. Discuss., in preparation, 2010.

Murphy, J. G., Day, D. A., Cleary, P. A., Wooldridge, P. J., Millet, D. B., Goldstein, A. H., and Cohen, R. C.: The weekend effect within and downwind of Sacramento - Part 1: Observations of ozone, nitrogen oxides, and VOC reactivity, Atmos. Chem. Phys., 7, 5327-5339, 2007, http://www.atmos-chem-phys.net/7/5327/2007/.

Müller, J.-F., Stavrakou, T., Wallens, S., De Smedt, I., Van Roozendael, M., Potosnak, M. J., Rinne, J., Munger, B., Goldstein, A., and Guenther, A. B.: Global isoprene emissions estimated using
MEGAN, ECMWF analyses and a detailed canopy environment model, Atmos. Chem. Phys., 8, 1329-1341, 2008,

http://www.atmos-chem-phys.net/8/1329/2008/.

Ohara, T., Akimoto, H., Kurokawa, J., Horii, N., Yamaji, K., Yan, X., and Hayasaka, T.: An Asian emission inventory of anthropogenic emission sources for the period 19802020, Atmos. Chem. Phys., 7, 4419-4444, 2007,

http://www.atmos-chem-phys.net/7/4419/2007/.

Paulot, F., Crounse, J. D., Kjaergaard, H. G., Kroll, J. H., Seinfeld, J. H., and Wennberg, P. O.: Isoprene photooxidation: new insights into the production of acids and organic nitrates, Atmos. Chem. Phys., 9, 1479-1501, 2009,

http://www.atmos-chem-phys.net/9/1479/2009/.

Pearson, G. and et al.: Remote sensing of the tropical rain forest boundary layer using pulsed Doppler lidar, Atmos. Chem. Phys. Discuss., in preparation, 2010.

Peeters, J., Nguyen, T. L., and Vereecken, L.: $\mathrm{HO}_{\mathrm{x}}$ radical regeneration in the oxidation of isoprene, Phys. Chem. Chem. Phys., 11, 5935-5939, doi: $\{10.1039 / b 908511 d\}, 2009$.

Pegoraro, E., Rey, A., Abrell, L., Vanharen, J. and Lin, G.: Drought effect on isoprene production and consumption in Biosphere 2 tropical rainforest, Glob. Change Biol., 12, 456-469, doi:10.1111/j.1365-2486.2006.01112.x, 2006.

Pike, R. C., Lee, J. D., Young, P. J., Moller, S., Carver, G. D., Yang, X., Misztal, P., Langford, B., Stewart, D., Reeves, C. E., Hewitt, C. N., and Pyle, J. A.: Can a global model chemical mechanism reproduce $\mathrm{NO}, \mathrm{NO}_{2}$, and $\mathrm{O}_{3}$ measurements above a tropical rainforest?, Atmos. Chem. Phys. Discuss., 9, 27611-27648, 2009, http://www.atmos-chem-phys-discuss.net/9/27611/2009/.

Pinho, P., Pio, C., and Jenkin, M.: Evaluation of isoprene degradation in the detailed tropospheric chemical mechanism, MCM v3, using environmental chamber data, Atmos. Environ., 39, 13031322, doi:\{10.1016/j.atmosenv.2004.11.014\}, 2005.

Poisson, N., Kanakidou, M., and Crutzen, P.: Impact of nonmethane hydrocarbons on tropospheric chemistry and the oxidizing power of the global troposphere: 3-dimensional modelling results, J. Atmos. Chem., 36, 157-230, 2000.

Pugh, T. and et al.: Nocturnal profiles of $\mathrm{NO}_{\mathrm{x}}$ and $\mathrm{O}_{3}$ over a SouthEast Asian rainforest, in preparation, 2010.

Real, E., Law, K. S., Schlager, H., Roiger, A., Huntrieser, H., Methven, J., Cain, M., Holloway, J., Neuman, J. A., Ryerson, T., Flocke, F., de Gouw, J., Atlas, E., Donnelly, S., and Parrish, D.: Lagrangian analysis of low altitude anthropogenic plume processing across the North Atlantic, Atmos. Chem. Phys., 8, $7737-$ 7754, 2008, http://www.atmos-chem-phys.net/8/7737/2008/.

Ren, X., Brune, W.H., Oliger, A., Metcalf, A.R., Simpas, J.B., Shirley, T., Schwab, J.J., Bai, C., Roychowdhury, U., Li, Y., Cai, C., Demerjian, K.L., He, Y., Zhou, X., Gao, H., and Hou, J.: $\mathrm{OH}, \mathrm{HO}_{2}$, and $\mathrm{OH}$ reactivity during the PMTACS-NY Whiteface Mountain 2002 campaign: Observations and model comparison, J. Geophys. Res., 111, D10S03, doi:10.1029/2005JD006126, 2006.

Ren, X., Olson, J. R., Crawford, J. H., Brune, W. H., Mao, J., Long, R. B., Chen, Z., Avery, M. A., Sachse, G. W., Barrick, J. D., Diskin, G. S., Huey, L. G., Fried, A., Cohen, R. C., Heikes, B., Wennberg, P. O., Singh, H. B., Blake, D. R. and Shetter, R. E.: $\mathrm{HO}_{\mathrm{x}}$ chemistry during INTEX-A 2004: Observation, model calculation, and comparison with previous studies, J. Geophys. 
Res., 113, D05310, doi:10.1029/2007JD009166, 2008.

Rosen, R. S., Wood, E. C., Wooldridge, P. J., Thornton, J. A., Day, D. A., Kuster, W., Williams, E. J., Jobson, B. T., and Cohen, R. C.: Observations of total alkyl nitrates during Texax Air Quality Study 2000: Implications of $\mathrm{O}_{3}$ and alkyl nitrate photochemistry, J. Geophys. Res., 109, D07303, doi:10.1029/2003JD004227, 2004.

Sander, R.: Compilation of Henry's Law Constants for Inorganic and Organic Species of Potential Importance in Environmental Chemistry (Version 3), online available at: http://www. henrys-law.org, 2009.

Saunders, S. M., Jenkin, M. E., Derwent, R. G., and Pilling, M. J.: Protocol for the development of the Master Chemical Mechanism, MCM v3 (Part A): tropospheric degradation of nonaromatic volatile organic compounds, Atmos. Chem. Phys., 3, 161-180, 2003,

http://www.atmos-chem-phys.net/3/161/2003/.

Schmitt, C., Belokurov, A., Besancon, C., Boisrobert, L., Burgess, N. D., Campbell, A., Coad, L., Fish, L., Gliddon, D., Humphries, K., Kapos, V., Loucks, C., Lysenko, I., Miles, L., Mills, C., Minnemeyer, S., Pistorius, T., Ravilious, C., and Winkel, G.: Global Ecological Forest Classification and Forest Protected Area Gap Analysis: Analyses and Recommendations in view of the $10 \%$ target for forest protection under the Convention on Biological Diversity (CBD), Freiburg University Press, Freiburg, Germany, 2008.

Shepson, P. B., Mackay, E., and Muthuramu, K.: Henry's law constants and removal processes for several atmospheric $\beta$-hydroxy alkyl nitrates, Enivron. Sci. Technol., 30, 3618-3623, 1996.

Sprengnether, M., Demerjian, K. L., Donahue, N. M., and Anderson, J. G.: Product analysis of the $\mathrm{OH}$ oxidation of isoprene and 1,3-butadiene in the presence of NO, J. Geophys. Res., 107, 4269, doi:10.1029/2001JD000716, 2002.

Stockwell, W., Kirchner, F., Kuhn, M., and Seefeld, S.: A new mechanism for regional atmospheric chemistry modeling, J. Geophys. Res., 102, 25847-25879, 1997.

Strong, J., Whyatt, J. D., Hewitt, C. N. and Derwent, R. G.: Development and application of a Lagrangian model to determine the origins of ozone episodes in the UK, Atmos. Environ., doi:10.1016/j.atmosenv.2009.11.019, in press, 2009.

Tan, D., Faloona, I., Simpas, J., Brune, W., Olson, J., Crawford, J., Avery, M., Sachse, G., Vay, S., Sandholm, S., Guan, H., Vaughn, T., Mastromarino, J., Heikes, B., Snow, J., Podolske, J., and Singh, $\mathrm{H} .: \mathrm{OH}$ and $\mathrm{HO}_{2}$ in the tropical Pacific: Results from PEM-Tropics B, J. Geophys. Res., 106, 32667-32681, 2001.

Tangki, H. and Chappell, A.: Biomass variation across selectively logged forest within a $225-\mathrm{km}^{2}$ region of Borneo and its prediction by Landsat TM, Forest Ecol. Manag., 256, 1960-1970, 2008.
Taraborrelli, D., Lawrence, M. G., Butler, T. M., Sander, R., and Lelieveld, J.: Mainz Isoprene Mechanism 2 (MIM2): an isoprene oxidation mechanism for regional and global atmospheric modelling, Atmos. Chem. Phys., 9, 2751-2777, 2009, http://www.atmos-chem-phys.net/9/2751/2009/.

Thornton, J. A., Wooldridge, P. J., Cohen, R. C., Martinez, M., Harder, H., Brune, W. H., Williams, E. J., Roberts, J. M., Fehsenfeld, F. C., Hall, S. R., Shetter, R. E., Wert, B. P., and Fried, A.: Ozone production rates as a function of $\mathrm{NO}_{\mathrm{x}}$ abundances and $\mathrm{HO}_{\mathrm{x}}$ production rates in the Nashville urban plume, J. Geophys. Res., 107(D12), 4146, doi:10.1029/2001JD000932, 2002.

Treves, K., Shragina, L., and Rudich, Y.: Henry's Law Constants of some $\beta$-, $\gamma$-, and $\delta$-Hydroxy Alkyl Nitrates of Atmospheric Interest, Environ. Sci. Technol., 34, 1197-1203, 2000.

Tucker, A. C., Brewer, W. A., Banta, R. M., Senff, C. J., Sandberg, S. P., Law, D. C., Weickmann, A. M. and Hardesty, R. M.: Doppler Lidar Estimation of Mixing Height Using Turbulence, Shear, and Aerosol Profiles, J. Atmos. Ocean Tech., 26, 673688, 2009.

Turnipseed, A. A., Huey, L. G., Nemitz, E., Stickel, R., Higgs, J., Tanner, D. J., Slusher, D. L., Sparks, J. P., Flocke, F., and Guenther, A.: Eddy covariance fluxes of peroxyacetyl nitrates (PANs) and $\mathrm{NO}_{\mathrm{y}}$ to a coniferous forest, J. Geophys. Res., 111, D09304, doi:10.1029/2005JD006631, 2006.

van Dijk, S. and Duyzer, J.: Nitric oxide emissions from forest soils, J. Geophys. Res., 104, 15955-15961, 1999.

Vinuesa, J.-F. and Vilà-Guerau de Arellano, J.: Introducing effective reaction rates to account for the inefficient mixing of the convective boundary layer, Atmos. Environ., 39, 445-461, 2005.

Walsh, R. P. D.: Climate, The Tropical Rain Forest, edited by: Richards, P. W., Cambridge University Press, Cambridge, 159205, 352 pp., 1996.

Whalley, L. K., Furneaux, K. L., Edwards, P. E., Heard, D. E.: The chemistry of $\mathrm{OH}$ and $\mathrm{HO}_{2}$ in a tropical rainforest, Atmos. Chem. Phys. Discuss., in preparation, 2010a.

Whalley, L. K., Furneaux, K. L., Edwards, P. E., and Heard, D. E.: Resolving the missing $\mathrm{OH}$ source in forested regions, Geophys. Res. Lett., in preparation, 2010b.

Wild, O., Law, K., McKenna, D., Bandy, B., Penkett, S., and Pyle, J.: Photochemical trajectory modeling studies of the North Atlantic region during August 1993, J. Geophys. Res., 101, 2926929288, 1996.

WMO: Scientific assessment of ozone depletion: 1995 Global Ozone Research and Monitoring Project, Geneva, Switzerland, 1995.

Yienger, J. and Levy, H.: Empirical model of global soil biogenic $\mathrm{NO}_{\mathrm{x}}$ emissions, J. Geophys. Res., 100, 11447-11464, 1995.

Zhang, L., Moran, M., Maker, P., Brook, J., and Gong, S.: Modelling gaseous dry deposition in AURAMS: a unified regional air-quality modelling system, Atmos. Environ., 36, 537-560, 2002. 